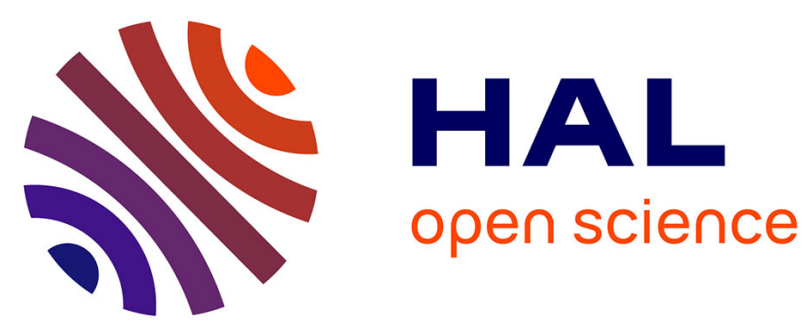

\title{
Topological and electrostatic properties of diclofenac molecule as a non-steroidal anti-inflammatory drug: An experimental and theoretical study
}

R. Niranjana Devi, A David Stephen, P. Justin, K. Saravanan, Piero Macchi, Christian Jelsch

\section{To cite this version:}

R. Niranjana Devi, A David Stephen, P. Justin, K. Saravanan, Piero Macchi, et al.. Topological and electrostatic properties of diclofenac molecule as a non-steroidal anti-inflammatory drug: An experimental and theoretical study. Journal of Molecular Structure, 2019, 1196, pp.42-53. 10.1016/j.molstruc.2019.06.027 . hal-02173126

\author{
HAL Id: hal-02173126 \\ https://hal.science/hal-02173126
}

Submitted on 4 Jul 2019

HAL is a multi-disciplinary open access archive for the deposit and dissemination of scientific research documents, whether they are published or not. The documents may come from teaching and research institutions in France or abroad, or from public or private research centers.
L'archive ouverte pluridisciplinaire HAL, est destinée au dépôt et à la diffusion de documents scientifiques de niveau recherche, publiés ou non, émanant des établissements d'enseignement et de recherche français ou étrangers, des laboratoires publics ou privés. 
Published in Journal of Molecular Structure, volume 1196 (2019), pp 42-53.

DOI: $10.1016 /$ j.molstruc.2019.06.027

\title{
Topological and electrostatic properties of diclofenac molecule as a non-steroidal anti-inflammatory drug: an experimental and theoretical study
}

R. Niranjana Devi a ${ }^{\text {a }}$ A. David Stephen ${ }^{\text {b* }}$, P. Justin ${ }^{\text {c }}$, K. Saravanan ${ }^{\text {d }}$, Piero Macchief ${ }^{\text {end }}$ Christian Jelsch ${ }^{\mathrm{g}}$

${ }^{a}$ Department of Physics, Fatima College, Madurai, 625018, India

${ }^{b}$ Department of Physics, Sri Shakthi institute of Engineering and Technology, Coimbatore, 641062, India

${ }^{c}$ School of Physics, Madurai Kamaraj University, Madurai, 625021, India

${ }^{d}$ Laboratory of Biocrystallography and Computational Molecular Biology, Department of Physics, Periyar University, Salem, 636011, India

${ }^{e}$ Department of Chemistry and Biochemistry, University of Bern, Bern, Switzerland

${ }^{f}$ Chemistry, Materials and Chemical engineering, Politecnico di Milano, Via Mancinelli 7, Milano, 20131, Italy

${ }^{g} C R M 2$, Lorraine University, CNRS, BP 70239, Vandoeuvre les Nancy, cedex, 54 506, France

Correspondence email: davidstephen_dav@yahoo.co.in

\begin{abstract}
Diclofenac is a Non-Steroidal Anti-Inflammatory Drug (NSAID), which highly inhibits the lipoxygenase pathways and reduces the formation of leukotriene lipids. In this work, we report on measurements and calculations of the electron density of Diclofenac, obtained from high resolution experimental X-ray diffraction data at $110 \mathrm{~K}$ and theoretical calculations. The supramolecular structure is dominated by the formation of a dimer through $\mathrm{COOH}$ homosynthon. The analysis of the molecular electron density (by means of quantum theory of atoms in molecules), the electrostatic potential, the crystal packing and intermolecular interactions (through Hirshfeld surface analysis) enables gaining more insight into the nature of the
\end{abstract}


molecule and its ability to interact with other molecules. Furthermore, the topological properties of the dimer interactions in both the crystal phase and human transthyretin protein environment were identified. The electrostatic potential map shows that the high electronegative regions appear around the carboxyl group of the diclofenac molecule in both the crystal and protein environment. This study is complemented by a molecular dynamics simulation of the interaction of diclofenac with transthyretin protein, which enables to test the hypothesis made with the charge density analysis.

\section{Keywords:}

Experimental Charge density, Hirshfeld surface analysis, topological properties, electrostatic interaction, Molecular Dynamics, Quantum Crystallography

\section{Introduction}

Diclofenac is the most prominent member of the Non-Steroidal Anti-Inflammatory Drugs (NSAIDs) [1], as it inhibits the enzyme cyclo-oxygenase COX-2 [2]. Diclofenac does also inhibit the Transthyretin (TTR) [3] protein that carries the thyroid hormone thyroxine $\left(\mathrm{T}_{4}\right)$ and retinol-binding protein bound to retinol. This is how transthyretin gained its name: transports thyroxine and retinol. The TTR protein exhibits a $\beta$-sheet homo-tetramericthree-dimensional structure and has two channels at the dimer-dimer interface.

This protein may be the main reason for familial amyloid polyneuropathy (FAP), an amyloid diseases caused by the TTR fibril formation over the heart and peripheral nerves. Diclofenac have been evaluated as a strong in vitro TTR amyloid inhibitor in the reverse mode which makes the rotation of dihalogen-substituted ring by $90^{\circ}$ with respect to phenylacetic moiety [4]. Diclofenac is the best alternative for NSAID drug flufenamic (FLU) [5], which is also a biphenylamine derivative with carboxylate substituent, however FLU binds with TTR in "forward mode". The in vitro analysis of this inhibition results with $17-56 \%$ reduction of TTR fibril formation [6].

To the best of our knowledge, the experimental electron density study for this compound has not been carried out till date. In order to shed light on the electronic structure of molecules and on the molecular recognition processes, high resolution X-ray diffraction measurements on crystals and charge density analysis were carried out. These kinds of studies enable the determination of the electron density distribution in molecular solids and, from this, a careful 
analysis of the electrostatic interactions. The charge density derived from experimental models can be compared with the theoretically derived, calculated in vacuo or under periodic boundary conditions, typically using density functional theory (DFT). The analysis of the static density, however, may not be enough for a full comprehension of the molecular aggregation and the intermolecular interactions. For this reason, molecular dynamics (MD) simulations may be useful to refine the binding conformation of the complex structure and to investigate the structural ability of a protein in the presence of ligands. Having this strategy in mind, we have undertaken a charge density analysis of diclofenac in order to obtain, from experiment and theory, an overview of its structural, topological, reactivity and electrostatic properties. In addition, molecular dynamic simulations were carried out to depict a sensible model of the actual binding mechanism. This study will provide pathway for exploration of new compounds with fewer side effects and a more sophisticated profile than already existing drug molecules, which is the focus of chemists and pharmacologists.

\section{Experimental details}

\subsection{Crystallization, $X$-ray data collection and structure solution}

The crystals of diclofenac were grown by slow evaporation method using ethanol solution. Among the harvested crystals, a good quality single crystal (ca. $0.12 \times 0.14 \times 0.19 \mathrm{~mm}$ ) was chosen for high resolution X-ray diffraction experiment. All measurements were made on an Oxford Diffraction Super Nova area-detector diffractometer using mirror optics monochromated Mo K $\alpha$ radiation $(\lambda=0.71073 \AA$ ) and Al filtered [7]. A total of 3600 frames were collected in 31 runs with data exposure of $10+10$ and $45+45$ seconds up to $\theta<48^{\circ}$, with a crystal-detector distance of $65.0 \mathrm{~mm}$, at $T=110(2) \mathrm{K}$. Data reduction was performed using the CrysAlisPro program [7]. The intensities were corrected for Lorentz and polarization effects, and an analytical absorption correction was applied, using SCALE3 ABSPACK in CrysAlisPro [8]. The smart-background data correction was adopted.

\subsection{Experimental multipole refinement}

The model was refined with MoPro software [9] using Hansen and Coppens [10] multipole model for pseudo-atom electron density. The $\mathrm{C}, \mathrm{N}$ and $\mathrm{O}$ atoms were refined up to octapole level, hydrogen atoms up to dipole level and chlorine atom was refined up to hexadecapole. The core and valence spherical scattering factors were calculated from Su \& Coppens [11] and the anomalous dispersion coefficients were taken from the International Tables for 
Crystallography [12]. The parameters of the Slater functions used to describe the multipoles are available in the deposited CIF file. The weighting scheme applied was $W_{\mathrm{hkl}}=1 / \sigma^{2}(I)$ and all reflections were used in all refinements. At first, after structural refinement, the $P_{\mathrm{lm}}$ multipole populations were refined. In the subsequent steps, the structural and charge density parameters were refined successively, in several cycles. In the final stages, all parameters were refined simultaneously till convergence.

According to the values found by the SHADE3 server [13], the $U_{i j}$ thermal displacements parameters were fixed for $\mathrm{H}$ atoms. The $\mathrm{H}-\mathrm{X}$ distances of $\mathrm{H}$ atoms were restrained to the standard values obtained from neutron diffraction studies [14] with a restraint sigma of $0.01 \AA$. The crystallographic details of the experimental refinements are given in Table 1. The chemically equivalent atoms in the structure were restrained to have similar charge density parameters $\left(\kappa, \kappa^{\prime}, P_{\mathrm{val}}, P_{\mathrm{lm}}\right)$ with a restraint sigma $\sigma_{\mathrm{r}}=0.01$ [15]. The electron density of atoms was restrained to follow the local symmetry $\left(\sigma_{\mathrm{r}}=0.01\right)$. For hydrogen, the $\kappa$ and $\kappa^{\prime}$ parameters of an atom were restrained to have similar values $\left(\sigma_{\mathrm{k}}=0.01\right)$ and the $\kappa$ values were restrained to be equal to $1.16(\sigma \mathrm{k}=0.03)$.

The most important properties such as the total electron density $\rho_{\mathrm{bcp}}(\mathrm{r})$, the Laplacian $\nabla^{2} \rho_{b c p}(r)$, the ellipticity $\varepsilon$ at the bond critical points and the eigenvalues $\left(\lambda_{1}, \lambda_{2}, \lambda_{3}\right)$ were calculated and the experimental deformation maps were estimated and plotted using VMoPro module of the MoPro software [9]. The residual indexes and the other parameters of multipole refinement are presented in Table 1 . The normal probability plot of $I_{\mathrm{obs}}-I_{\mathrm{calc}}$ and the evolution of $I_{\text {obs }} / I_{\text {calc }}$ as a function of reciprocal resolution $\sin \theta / \lambda$ is shown in Fig. Sup1 and Sup2 [16]. The fractal dimension plot of the residual electron density is shown in Fig. Sup3[17].

\section{Theoretical calculations}

A density functional calculation (DFT) was performed in order to understand the electronic and reactivity properties for the drug diclofenac using GAUSSIAN09 software [18]. Singlepoint calculations were performed once the convergence was reached. The absence of imaginary frequencies showed that the minimum energy structure had been achieved. Similarly, after the MD simulation, the diclofenac molecule with active site amino acids was taken for the single point energy minimization to generate the wave function. The obtained wave function for the gas phase of diclofenac molecule and active site region were given as an input to the AIM2000 package [19] for calculating the topological properties. 


\subsection{Molecular Dynamics Simulation}

To perform MD simulation, three-dimensional coordinates of the human transthyretin complexed with diclofenac (1DVX) complex were retrieved from the Protein Databank. The input parameters for the MD simulations were prepared using the default protein force fields and the ligand parameters were generated using GAFF force field. The complex was placed at the centre of the box and TIP3P water molecules [20] from the AMBER solvent library were added into it. Necessary sodium ions were added to neutralize the system. Periodic boundary conditions were used to treat the boundary of the system to minimize the edge effects. Particle Mesh Ewald (PME) was used to treat electrostatic interactions, the PME grid size was $73 \times 69 \times 82 \AA$. The resulting system was minimized for 1000 steps and the temperature was maintained at $300 \mathrm{~K}$ throughout the simulation and pressure (1 bar) using the same Langevin thermostat and Berendsen barostat used in the heating process [21,22]. $20 \mathrm{~ns}$ MD simulation was carried out to find out the stability of diclofenac at the active site of human transthyretin using the molecular dynamics software NAMD [23] with the time step of one femto-second. VMD [24] and CPPTRAJ [25] software were used to generate the MD trajectory.

\section{Results and discussion}

\subsection{Crystal structure description}

The crystal volume of diclofenac at $110 \mathrm{~K}$ is $3.9 \%$ smaller than at ambient conditions, as reported by Muangsinet al. [26]. The molecular structure is shown in Figure 1 as an ORTEP plot. The 2,6-dichlorophenyl ring and the acid chain lie almost perpendicular to the central ring. Despite forming a strong hydrogen bonded dimer, the single and double bond characters of the C-O bonds are quite evident: C1-O2 is shorter [1.2314(6) $\AA]$ than C1-O1 [1.3080(8) $\AA]$ (see also Table Sup 1). Compared with the standard C-N bond lengths [27], it is evident that some delocalization occurs in the $\mathrm{C}-\mathrm{N}$ bonds $[\mathrm{C} 8-\mathrm{N} 1=1.414(5) \AA, \mathrm{C} 9-\mathrm{N} 1=1.3939(5) \AA]$. This is further confirmed by $\mathrm{C} 8-\mathrm{N} 1-\mathrm{C} 9$ angle $\left[122.73(3)^{\circ}\right]$ being larger than that of a tetrahedral angle which is expected for $\mathrm{N} 1$ atom. The electron lone pair of $\mathrm{N} 1$ is weakly visible in the electron density map and is involved in the resonance. Another reason for the large angle might be the C9 atom is attached with the 2,6-dichlorophenyl ring. In order to get details regarding the distortion in bond angles, the deformation of C-C-C valence angles has been calculated for the 2,6-dichlorophenyl ring and the other phenyl ring separately. The root means square deviations from the ideal $120^{\circ}$ value of the hexagonal angles is computed as: 


$$
\sigma_{\text {hexagon }}=\sqrt{\sum_{i=1}^{6} \frac{\left(\theta_{i}-120^{\circ}\right)^{2}}{6}}
$$

It is found that the distortion in angle for the 2,6-dichlorophenyl ring is higher $\left(\sigma_{\text {hexagon }}=2.2^{\circ}\right.$ ) than that of the other phenyl ring of the molecule $\left(\sigma\right.$ hexagon $\left.=0.65^{\circ}\right)$ and the reason might be presence of the two $\mathrm{Cl}$ atoms and their electron withdrawing effect on the $\mathrm{C} 6$ ring.

\subsection{Crystal packing and intermolecular interactions}

The main feature of the supramolecular packing is the coupling of two carboxylic groups forming a strongly hydrogen bonded dimer (Fig.2a), through O1-H1B $\cdots \mathrm{O} 2$ interactions. The packing of the molecule along $\boldsymbol{b}$ axis is given in Fig.2b.There are anyway other contacts, such as $\mathrm{C}-\mathrm{H} \cdots \mathrm{Cl}$ and $\mathrm{C}-\mathrm{H} \cdots \mathrm{O}$, that also give contributions to the packing of the crystal. The Hirshfeld surface analysis $[28,29]$ summarises all the contributions and it certainly highlights major role played by $\mathrm{O} 1-\mathrm{H} 1 \mathrm{~B} \cdots \mathrm{O} 2$ interaction (Fig.3). The hydrogen bonding details are given in Table 2 There is limited non-parallel cycle stacking present between 2,6-dichlorophenyl rings. A dimer formed via an inversion centre results in a $\mathrm{Cl} \cdots \mathrm{Cl}$ distance of $3.576 \AA$ which is shorter than the sum of Van der Waals radii (Fig. 3b). The experimental $\mathrm{Cl} \cdots \mathrm{Cl}$ interaction which is traced in our molecule is comparable with the type I trans $\mathrm{Cl} \cdots \mathrm{Cl}$ geometry as reported by Hathwar and Guru Row [30].

The fingerprint analysis (Fig.4) [31] shows that $\mathrm{H} \cdots \mathrm{H}$ contacts (Fig. 4b) give the largest contribution, which is about $32.5 \%$. The $\mathrm{Cl} \cdots \mathrm{H} / \mathrm{H} \cdots \mathrm{Cl}$ (Fig.4c) and $\mathrm{O} \cdots \mathrm{H} / \mathrm{H} \cdots \mathrm{O}$ hydrogen bonds (Fig.4d) also render a significant contribution of $18.7 \%$ and $13.6 \%$ respectively to the packing.

\subsection{Contact Enrichment Ratio Analysis}

The contacts enrichments [32] have been analysed with software MoPro Viewer[33]. The enrichment ratio, which compares the actual contacts with equi-probable theoretical contacts (derived from the chemical content on the surface), enables to see if interactions are over or under-represented. Hydrophobic hydrogen atoms $\mathrm{Hc}$ bound to $\mathrm{C}$ were distinguished from polar $\mathrm{Hp}$ atoms bound to $\mathrm{O}$ or $\mathrm{N}$ atoms. The four major contacts are hydrophobic, of type $\mathrm{C} \cdots \mathrm{Hc}$, $\mathrm{C} \cdots \mathrm{Cl}, \mathrm{Cl} \cdots \mathrm{Hc}$ and $\mathrm{Hc} \cdots \mathrm{Hc}$ (Table 3, Fig. 5). Among these four contacts, three are close to a balanced representation $(E \approx 1)$ while $\mathrm{Cl} \cdots \mathrm{C}$ contacts are significantly over-represented with $E_{\mathrm{C} . \mathrm{Cl}}=1.54$ due to numerous $\mathrm{C}-\mathrm{Cl} \cdots \mathrm{C}$ interactions. Weak hydrogen bonds of type $\mathrm{Cl} \cdots \mathrm{Hc}$ are also well represented. 
According to the recent study by Eskandariet al. [34], halogen bonding can be described as an interaction between a depleted region also known as a $\sigma$-hole on the halogen atom and a charge concentrated region also known as a lump on the other molecule. One $\mathrm{Cl} \cdots \mathrm{Cl}$ halogen bond occurs in the crystal (Fig. 3b) but this type of contact is under-represented, similarly to the $\mathrm{Cl} \cdots \mathrm{O}$ halogen bonds. The $\mathrm{C} \cdots \mathrm{C}$ contacts are impoverished at $E=0.68$ due to the occurrence of very limited non-parallel cycle stacking. $\mathrm{C} \cdots \mathrm{Hc}$ contacts are more represented as significant $\mathrm{C}$ $\mathrm{H} \cdots \pi$ interactions are seen, notably between phenyl rings forming an angle of $85.1^{\circ}$ and related by two-fold helical axis of direction $\mathbf{b}$ (Fig. 2b).

The most enriched contact at $E=5.0$ is between polar $\mathrm{Hp}(\mathrm{H}-\mathrm{O}$ and $\mathrm{H}-\mathrm{N})$ hydrogen atoms and oxygen, although it represents less than $5 \%$ of the contact surface. The $\mathrm{O} \cdots \mathrm{H}-\mathrm{O}$ strong double hydrogen bond constitutes the most attractive electrostatic interaction in the crystal packing. Besides that, the oxygen atoms are mostly involved in weak $\mathrm{C}-\mathrm{H} \cdots \mathrm{O}$ hydrogen bonds which are slightly favoured at $E_{\mathrm{O} . \mathrm{Hc}}=1.06$. The nitrogen atom, despite its hydrogen bond acceptor potential, is mostly surrounded by carbon atoms. On the other hand, the H-N nitrogen atoms which forms an intramolecular hydrogen bonds with the $\mathrm{C} 1=\mathrm{O} 2$ carbonyl is only surrounded by Hc atoms. Globally, the molecular surface contains $86 \%$ of hydrophobic atoms $(\mathrm{C}, \mathrm{Hc}, \mathrm{Cl})$ and $14 \%$ of hydrogen bond donors/acceptors $(\mathrm{Hp}, \mathrm{O})$. When this partition of the molecule is considered, it can be derived from Table 3, that the contacts between hydrophilic contacts appear quite enriched at $E=2.6$. The hydrophobic ones are slightly overrepresented at $E=1.04$ while cross contacts between polar/non-polar atoms are significantly disfavoured at $E=0.76$.

\subsection{Molecular electron density}

The quality of the high resolution data and the multipole model is attested by the residual density map for the phenyl ring in the molecule and is shown in Fig.6.

The topological properties of the electron density are listed in Table 4 and in Table S2 of the Supporting information. The most relevant results concern the heteronuclear $\mathrm{Cl}-\mathrm{C}$ and the $\mathrm{C}$ $\mathrm{N}$ bonds. The $\mathrm{C}-\mathrm{Cl}$ bonds show lower magnitudes of $\rho(\mathbf{r})$ and $\nabla^{2} \rho(\mathbf{r})$ at the bond critical point. This reflects the weak shared interactions occurring between these atoms. Moreover, the bonding density peaks are closer to the carbon atom and their positions do not correspond to that of the CPs, resulting in weaker $\rho\left(\mathbf{r}_{\mathrm{cp}}\right)$ and $\nabla^{2} \rho\left(\mathbf{r}_{\mathrm{cp}}\right)$ values. The electron density was found to be polarized towards the chlorine atom, bearing the negative charge. The corresponding experimental/theoretical electron density and Laplacian of electron density for the C14-C11 and C10-C12 bond critical points are 1.29/1.35e $\AA^{-3} ; 1.31 / 1.38 \mathrm{e} \AA^{-3}$ and -1.8/-7.2 e $\AA^{-5} ;-2.2 /-7.6 \mathrm{e} \AA^{-}$ 
${ }^{5}$ respectively, and this was well agreed with the earlier reported values [35]. We note that theoretical calculations predict the critical point closer to the region of negative Laplacian of the Chlorine atoms, at variance from the multipolar model adopted for the experimental electron density.

As anticipated in section 4.1, the C-N bonds display values which are larger than for typical single bonds and effects of the electron delocalization are visible. Anyway, the two bonds are

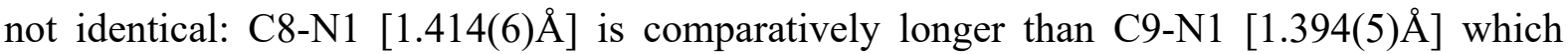
shows a weaker $\pi$-donating effect of the amine nitrogen atom towards the phenyl ring compared to the 2,6-dichlorophenylring.

As for the two C-O bonds, $\mathrm{C} 1-\mathrm{O} 2$ is stronger and it clearly shows the localized nature of the double bond, compared with $\mathrm{C} 1-\mathrm{O} 1$, a localized single bond. In fact, at the bond critical points, the electron density is $2.83 \mathrm{e} / \AA^{3}$ (Expt.) or $2.70 \mathrm{e} / \AA^{3}$ (Theor.) for $\mathrm{C} 1-\mathrm{O} 2$ and $2.33 \mathrm{e} / \AA^{3}$ (Expt.) or $2.17 \mathrm{e} / \AA^{3}$ (Theor.) for $\mathrm{C} 1-\mathrm{O} 1$.

The deformation maps in the 2,6-dichlorophenyl (Fig. 7a) and phenyl ring (Fig. 7b) provide a pictorial view of the electron density depicting the bonding regions and electron lone pairs of the molecule. This information is in keeping with that provided by the Laplacian maps(Fig. 8a$8 c)$.

\subsection{Molecular electrostatics}

The molecule features some regions of strongly negative electrostatic potentials and others dominated by a positive potential. Of course, this mirrors the distribution of charges in the molecule. The carboxylic group consists of carbon $\mathrm{C} 1$, which bears the highest positive QTAIM charge $(+1.536 \mathrm{e}$, see Table 5) and of the two electronegative $\mathrm{O}$ atoms $\mathrm{O} 1(-1.071 \mathrm{e})$ and $\mathrm{O} 2(-1.245 \mathrm{e})$. Comparatively, the $\mathrm{O} 2$ atom $(\mathrm{O} 2=\mathrm{C})$ has slightly more negative charge than the $\mathrm{O} 1$ atom $(\mathrm{C} 1-\mathrm{O} 1-\mathrm{H} 1 \mathrm{~B})$. The aminic $\mathrm{N} 1$ atom bears the second most negative charge and the electron rich region around the atom is clearly seen in the Fig. 9b. The group charges on the 2,6-dichlorophenyl ring, the other phenyl ring and the acid chain are calculated as $+0.285 \mathrm{e}$, $+0.367 \mathrm{e}$ and $+0.030 \mathrm{e}$, respectively. The phenyl ring has an electropositive contribution on the molecule while the 2,6-dichlorophenyl ring is more electronegative. The $\mathrm{Cl} 2$ atom has slightly larger volume $\left(109.6 \AA^{3}\right)$ than the $\mathrm{Cl1}$ atom $\left(102.1 \AA^{3}\right)$ (as listed in Table 5).

The electrostatic potential maps of the intermolecular interactions are shown in Fig. 9c in which, the high negative potential is observed around the vicinity of carboxyl group of the 
diclofenac molecule in both the crystal and TTR protein environment. From this, it was confirmed that the carboxyl group of diclofenac molecule plays an important role in the drugreceptor interactions.

\subsection{Topological properties for Intermolecular interactions in crystal and active site phase}

Topological properties of the strong intermolecular interactions in the crystal and protein environment were determined by using charge density analysis to understand the strength of intermolecular interactions at electronic level, which plays vital role in the molecular recognition of bio-systems [36,37]. Numerous reports clearly explained about the topological properties of intermolecular interactions [38-42]. However, the same properties were calculated and compared for diclofenac molecule in the solid state and human transthyretin enzyme environment with the help of $(3,-1)$ type of critical point search. In the crystal phase, the electron density and Laplacian of electron density of $\mathrm{H}(1 \mathrm{~B}) \cdots \mathrm{O}(2)$ interaction is $0.30 \mathrm{e}^{-3}$ and $5.19 \mathrm{e}^{-5}$ respectively. The Laplacian map of the interaction is shown in Fig. 10a,b; a lone pair of the oxygen atom is directed towards the hydrogen atom. The carboxyl group of the diclofenac molecule forms strong dimer interactions in the solid state and the same group forms strong interaction in the protein environment. In the human transthyretin-diclofenac complex, the electron density and Laplacian of electron density of $\mathrm{O}(2) \cdots \mathrm{H}-\mathrm{O}$ Ser1 17 interaction is 0.149 $\mathrm{e} \AA^{-3}$ and $2.113 \mathrm{e}^{-5}$ respectively and the interaction is shown in Fig. 10c. On comparing both the electron density and Laplacian of electron density of the particular interaction in the solid state and protein phase, the $\rho\left(\mathbf{r}_{\mathrm{bcp}}\right)$ and $\nabla^{2} \rho\left(\mathbf{r}_{\mathrm{bcp}}\right)$ values are decreased when the molecule enters into the active site of human transthyretin enzyme. This is strongly attributed to the effect of the protein environment. Furthermore, the total energy densities of the intermolecular interactions were calculated from the sum of kinetic energy and potential energy as stated by viral theorem [43-45]. The topological properties $\left[\rho\left(\mathbf{r}_{\mathrm{bcp}}\right)\right.$ and $\left.\nabla^{2} \rho\left(\mathbf{r}_{\mathrm{bcp}}\right)\right]$, the total energy density $\left(H_{\mathrm{r}}\right)$, potential energy density $\left(V_{\mathrm{r}}\right)$, kinetic energy density $\left(G_{\mathrm{r}}\right)$, bond dissociation energy $(D)$, bond path length $\left(R_{\mathrm{ij}}\right)$ and bond critical point distances $\left(d_{1}\right.$ and $\left.d_{2}\right)$ of intermolecular interactions are presented in Table 6. The negative kinetic energy dominates the potential energy and, as a result, the total energies are negative.

\subsection{Reactivity properties}

The analysis on HOMO-LUMO plays a vital role in explaining the process of charge transfer within the molecule. The HOMO-LUMO energy gap characterizes the kinetic stability and 
chemical reactivity of the molecule. Some global reactivity descriptors such as electron affinity [46], ionization potential, hardness [47,48], softness, electronegativity [49] and electrophilicity index $[50,51]$ help us to characterize the nature and interaction of the molecule. The reactivity descriptors have been listed in Table 7. The low energy gap between the donor and acceptor shows that the transfer of energy takes place well between them. The very low electron affinity (0.031a.u.) and low ionization potential (0.213a.u.) says that the molecule has low kinetic stability as well as high chemical reactivity. The very low global hardness value (0.091a.u.) and very high softness value (5.495a.u.) pronounces that the molecule is ready to share electrons and it is termed as very soft molecule. The very low electronegativity (0.122a.u.) predicts that the molecule has very low attraction for electrons. Moreover, the low electrophilicity index (0.086a.u.) tells that the molecule can act as nucleophile which could donate electrons while interacting with the bio-molecule.

\subsection{Intermolecular interactions and stability of the complex}

MD simulation is a trustful tool to validate the conformational changes, stability of human transthyretin-diclofenac complex and intermolecular interactions. The stable conformation of diclofenac was positioned initially in the active site, as in the PDB coordinates file.

There are few statistical parameters to evaluate the conformational stability and strength of intermolecular interactions such as root mean square deviation (RMSD), root mean square fluctuation (RMSF), radius of gyration $\left(R_{\mathrm{g}}\right)$ and number of hydrogen bonding in the proteinligand complex. The RMSD of the transthyretin-diclofenac complex was calculated with respect to initial coordinates to understand the deviation of the backbone of the protein. The maximum RMSD of the complex is $1.5 \AA$, which indicates that the complex is stable during the 20 ns of MD simulation (Fig.11 and Fig. 12). The RMSF of the transthyretin-diclofenac complex clearly indicates that larger fluctuation was noticed in the loop regions of the complex than in the $\alpha$-helix and $\beta$-sheet domain. The maximum fluctuation of the complex during the simulation is $\sim 3 \AA$ in the loop region which is not stabilized by intermolecular interactions. Particularly, the active site amino acids are not fluctuating highly; the RMSF of these amino acids is $\sim 2 \AA$. The radius of gyration of the transthyretin-diclofenac complex is determined to understand the compactness of the protein when the ligand molecule enters into the active site of the protein. The average $R_{\mathrm{g} g y r a t i o n}$ radius value of the transthyretin-diclofenac complex is $\sim 17.7663 \AA$ (with standard deviation of 0.10848); which indicates that the complex is highly stable during the MD simulation. The number of hydrogen bonding interactions in the 
transthyretin-diclofenac complex comprise $\sim 120$ (within the protein) and 3 (between the protein and ligand) (Fig. 11d). Notably, the carboxyl group of the diclofenac molecule is forming strong interactions with active site residues which is clearly shown in the Fig. 12. Apart from the direct hydrogen bonds, water mediated hydrogen bonds and hydrophobic clusters stabilize also the orientation. The H-C hydrogen atoms involved in the cluster formation belong to amino acids SER 108, THR 109, THR 110 and SER 221. The electrophilic and nucleophilic regions of the ligands interact with the nucleophilic and electrophilic regions of the protein active site, respectively. The Connolly surface view of the transthyretindiclofenac complex clearly shows the binding cavity. The superimposed view of the transthyretin-diclofenac complex also confirms its stability (Fig.12). On comparing the crystal and simulated transthyretin-diclofenac complex, the relative orientation of the dichlorobenzene and phenyl ring of the diclofenac molecule is different; this can clearly be attributed to the effect of interactions and to the dynamical behaviour.

\section{Conclusion}

The experimental electron density analysis of the diclofenac molecule was performed at $110 \mathrm{~K}$ using high-resolution X-ray diffraction data. The aminic N1 atom, which has three bonds, could be expected to have tetrahedral geometry $\left(\mathrm{sp}^{3}\right)$. The structure analysis shows that it is, instead, closer to a trigonal geometry $\left(\mathrm{sp}^{2}\right)$ but it still has a weak electron lone pair. This can be attributed to the involvement of $\mathrm{N} 1$ atom in resonance primarily with the aromatic 2,6dichlorophenyl ring. The C8-N1 bond is comparatively longer than the bond C9-N1 which shows a weaker $\pi$-donating effect of the amine nitrogen atom towards the phenyl ring than towards the 2,6-dichlorophenyl ring.

The interaction between two parallel aromatic rings results in a $\mathrm{Cl}$... Cl distance shorter than the sum of van der Waals radii. The $\mathrm{O} 2=\mathrm{C} 1$ oxygen atom is considered to be the most nucleophilic and it is the preferred site of electrophilic attack. The drug proves as a potent drug and physiologically active according to the Lipinski rule of five parameters. The reactivity descriptors describes that diclofenac has high chemical reactivity, is very soft and is a fast interacting drug with the biomolecules. The molecular dynamics simulation, started from crystal structure of the complex, shows a clear picture of the interaction between the diclofenac molecule and the amino acid residues present in the human transthyretin protein. 
Table 1 Crystallographic and refinement details.

\begin{tabular}{|c|c|}
\hline \multicolumn{2}{|l|}{ Crystal data } \\
\hline Chemical formula & $\mathrm{C}_{14} \mathrm{H}_{11} \mathrm{Cl}_{2} \mathrm{NO}_{2}$ \\
\hline$M_{\mathrm{r}}$ & 296.14 \\
\hline Crystal system, space group & Monoclinic, $C 2 / c$ \\
\hline Temperature $(\mathrm{K})$ & 110 \\
\hline$a, b, c(\AA)$ & $20.0817(2), 6.8873(4), 19.8429(2)$ \\
\hline$\beta\left(^{\circ}\right)$ & $109.749(1)$ \\
\hline$V\left(\AA^{3}\right)$ & 2583.02(4) \\
\hline$Z$ & 8 \\
\hline Radiation type & Mo $K \alpha$ \\
\hline$\mu\left(\mathrm{mm}^{-1}\right)$ & 0.50 \\
\hline Crystal size (mm) & $0.12 \times 0.14 \times 0.19$ \\
\hline \multicolumn{2}{|l|}{ Data collection } \\
\hline Diffractometer & Oxford Diffraction SuperNova \\
\hline Absorption correction & Multiscan(Abspack, CrysAlisPro 1.171.38.43) \\
\hline$T_{\min }, T_{\max }$ & $0.705,1.00$ \\
\hline $\begin{array}{l}\text { No. measured;unique; } \\
\text { observed }[I>2 \sigma(I)] \text { reflections }\end{array}$ & $109947 ; 12271 ; 9581$ \\
\hline$(\sin \theta / \lambda)_{\max }\left(\AA^{-1}\right)$ & 1.043 \\
\hline \multicolumn{2}{|l|}{ Refinement } \\
\hline$R\left[F^{2}>2 \sigma\left(F^{2}\right)\right], w R\left(F^{2}\right), S$ & $0.034,0.054,0.982$ \\
\hline No. of reflections & 11436 \\
\hline No. of parameters & 609 \\
\hline H-atom treatment & $\begin{array}{l}\mathrm{H} \text { atoms treated by a mixture of independent and } \\
\text { constrained refinement }\end{array}$ \\
\hline$\Delta \rho_{\max }, \Delta \rho_{\min }\left(\mathrm{e} \AA^{-3}\right)$ & $0.41,-0.41$ \\
\hline
\end{tabular}


Table 2 Hydrogen bonding details.

\begin{tabular}{|l|l|l|l|l|}
\hline Bonds & $\mathbf{D}-\mathbf{H}(\mathbf{\AA})$ & $\mathbf{H} \cdots \mathbf{A}(\AA)$ & $\mathbf{D} \cdots \mathbf{A}(\AA)$ & $\mathbf{D}-\mathbf{H}^{\prime} \cdots \mathbf{A}\left({ }^{\mathbf{0}}\right)$ \\
\hline $\mathrm{O} 1-\mathrm{H} 1 \mathrm{~B} \cdots \mathrm{O} 2^{\# 1}$ & 0.979 & 1.649 & $2.628(1)$ & 178.1 \\
$\mathrm{C} 2-\mathrm{H} 2 \mathrm{~A} \cdots \mathrm{O} 2^{\# 2}$ & 1.071 & 2.562 & $3.633(1)$ & 166.3 \\
$\mathrm{C} 6-\mathrm{H} 6 \cdots \mathrm{Cl1}^{\# 3}$ & 1.031 & 2.771 & $3.802(1)$ & 150.0 \\
\hline
\end{tabular}

Symmetry codes: $\# 1 .-\mathrm{X}+1 / 2 ;-\mathrm{Y}+5 / 2 ;-\mathrm{Z}+1 \quad \# 2 .-\mathrm{X}+1 / 2 ;-\mathrm{Y}+3 / 2 ;-\mathrm{Z}+1, \# 3 .-\mathrm{X}+1 ; \mathrm{Y} ;-\mathrm{Z}+3 / 2$

Table 3 Nature of intermolecular contacts on the Hirshfeld surface by chemical types.

\begin{tabular}{|c|ccc|cc|}
\hline chem. & $\mathrm{C}$ & $\mathrm{Hc}$ & $\mathrm{Cl}$ & $\mathrm{Hp}$ & $\mathrm{O}$ \\
\hline surf. \% & 29.5 & 35.1 & 20.8 & 5.6 & 8.3 \\
\hline $\mathrm{C}$ & 5.7 & & & & \\
$\mathrm{Hc}$ & $\mathbf{2 1 . 8}$ & $\mathbf{1 2 . 6}$ & & \% contacts & \\
$\mathrm{Cl}$ & $\mathbf{1 8 . 8}$ & $\mathbf{1 4 . 7}$ & 2.3 & & \\
$\mathrm{Hp}$ & 1.3 & 2.6 & 2.5 & 0.2 & \\
$\mathrm{O}$ & 3.6 & 6.2 & 1.9 & 4.8 & 0.0 \\
\hline $\mathrm{C}$ & 0.68 & & & & \\
$\mathrm{Hc}$ & 1.07 & 1.02 & & enrichment & \\
$\mathrm{Cl}$ & $\mathbf{1 . 5 4}$ & 0.98 & 0.50 & & \\
$\mathrm{nyp}$ & 0.37 & 0.63 & 1.03 & 0.61 & \\
$\mathrm{O}$ & 0.75 & 1.06 & 0.53 & $\mathbf{5 . 0}$ & 0.00 \\
\hline
\end{tabular}

The second row contains the contribution $S_{\mathrm{X}}$ of each chemical type X on the Hirshfeld. The third part of the Table show the $\% C_{x y}$ of the contact types on the surface. The lower part of the Table shows the $E_{\mathrm{xy}}$ enrichment ratios of contact types. The major $C_{\mathrm{xy}}$ contact types and the $E_{\mathrm{xy}}$ ratios larger than unity (corresponding to the significantly enriched contacts) are highlighted in bold characters. The hydrophobic Hc atoms bound to carbon were distinguished from the more polar Hp hydrogen atom from the $\mathrm{COOH}$ and $\mathrm{NH}$ groups. Chemical types have been regrouped in hydrophobic $(\mathrm{C}, \mathrm{Hc}, \mathrm{Cl})$ and charged $(\mathrm{Ho}, \mathrm{O})$ atoms. $\mathrm{N}$ chemical type is omitted as it represents only $0.5 \%$ on the contact surface. 
Table 4 Topological properties of the electron density at the bond critical points of Diclofenac.

\begin{tabular}{|c|c|c|c|c|c|}
\hline Bonds & $\begin{array}{l}\rho_{\text {bcp }} \\
\left(\mathbf{e} / \AA^{3}\right)\end{array}$ & $\begin{array}{l}\nabla^{2} \rho_{\text {bcp }} \\
\left(\mathbf{e} / \AA^{5}\right)\end{array}$ & $\varepsilon$ & $\begin{array}{l}d_{1} \\
(\AA)\end{array}$ & $\begin{array}{l}d_{2} \\
(\AA)\end{array}$ \\
\hline$(\mathrm{C}-\mathrm{C})_{\text {aro }}$ & $2.1(2)$ & $-18.4(6)$ & $0.198(2)$ & 0.697 & 0.617 \\
\hline $\mathrm{C} 2-\mathrm{C} 3$ & $1.65(2)$ & $-9.4(5)$ & $0.0(2)$ & 0.728 & 0.785 \\
\hline C14-C11 & $1.29(1)$ & $-1.8(4)$ & $0.11(5)$ & 0.96 & 0.777 \\
\hline $\mathrm{C} 10-\mathrm{Cl} 2$ & $1.31(2)$ & $-2.2(5)$ & $0.02(5)$ & 0.956 & 0.769 \\
\hline $\mathrm{C} 1-\mathrm{O} 1$ & $2.33(4)$ & $-27.7(2)$ & $0.09(3)$ & 0.813 & 0.495 \\
\hline $\mathrm{C} 1-\mathrm{O} 2$ & $2.83(8)$ & $-22.2(7)$ & $0.18(4)$ & 0.814 & 0.417 \\
\hline C8-N1 & $2.00(2)$ & $-16.6(1)$ & $0.12(2)$ & 0.822 & 0.593 \\
\hline C9-N1 & $2.13(3)$ & $-15.7(1)$ & $0.14(4)$ & 0.78 & 0.614 \\
\hline$(\mathrm{C}-\mathrm{H})_{\text {aro }}$ & $1.82(2)$ & $-16.8(7)$ & $0.04(2)$ & 0.723 & 0.359 \\
\hline$(\mathrm{C}-\mathrm{H})_{\mathrm{sp} 3}$ & $1.74(0)$ & $-13.9(0)$ & $0.01(1)$ & 0.716 & 0.375 \\
\hline O1-H1B & $2.10(4)$ & $-23.7(3)$ & $0.003(4)$ & 0.754 & 0.226 \\
\hline N1-H1A & $2.03(4)$ & $-21.2(1)$ & $0.05(2)$ & 0.756 & 0.259 \\
\hline
\end{tabular}

Table 5 Experimental integrated topological atomic charges and volumes.

\begin{tabular}{|lr|lr|}
\hline Atom & $\boldsymbol{Q ( e )}$ & Atom & $\boldsymbol{Q ( e )}$ \\
\hline C11 & -0.157 & C11 & -0.022 \\
C12 & -0.177 & C12 & -0.124 \\
\hline O1 & -1.071 & C13 & -0.024 \\
O2 & -1.245 & C14 & -0.009 \\
\hline N1 & -1.111 & H2A & 0.132 \\
\hline C1 & 1.536 & H2B & 0.132 \\
C2 & -0.048 & H4 & 0.147 \\
C3 & -0.146 & H5 & 0.129 \\
C4 & -0.218 & H6 & 0.129 \\
C5 & -0.009 & H7 & 0.189 \\
C6 & -0.121 & H11 & 0.148 \\
C7 & 0.013 & H12 & 0.14 \\
C8 & 0.253 & H13 & 0.16 \\
C9 & 0.28 & H1A & 0.444 \\
C10 & 0.053 & H1B & 0.597 \\
\hline
\end{tabular}


Table 6. Topological properties of electron density for the main intermolecular interactions in the crystal phase and active site region. $G$ and $V$ are the kinetic, potential energy respectively.

\begin{tabular}{|c|c|c|c|c|c|c|c|}
\hline Bond & $\begin{array}{l}\rho_{\mathrm{cp}}\left(\mathrm{r}_{\mathrm{cp}}\right) \\
\mathbf{e} / \AA^{\mathbf{3}}\end{array}$ & $\begin{array}{l}\nabla^{2} \rho\left(\mathbf{r}_{\mathrm{cp}}\right) \\
\mathrm{e} / \AA^{5}\end{array}$ & Ellip. & $\begin{array}{c}G\left(\mathrm{r}_{\mathrm{cp}}\right) \\
\mathrm{au}\end{array}$ & $\begin{array}{c}V\left(\mathbf{r}_{\mathrm{cp}}\right) \\
\mathrm{au}\end{array}$ & $\begin{array}{l}d_{1} \\
(\AA ̊)\end{array}$ & $\begin{array}{l}d_{2} \\
(\AA))\end{array}$ \\
\hline $\mathrm{O} 1-\mathrm{H}(1 \mathrm{~B}) \cdots \mathrm{O} 2^{\# 1}$ & $0.301(3)$ & $5.19(5)$ & $0.03(2)$ & 0.052 & -0.050 & 1.649 & 1.114 \\
\hline $\mathrm{C} 2-\mathrm{H}(2 \mathrm{~A}) \cdots \mathrm{O} 2^{\# 2}$ & $0.033(2)$ & $0.64(2)$ & $0.11(1)$ & 0.005 & -0.003 & 1.554 & 1.023 \\
\hline $\mathrm{C} 6-\mathrm{H} 6 \cdots \mathrm{Cl}^{\# 3}$ & $0.038(2)$ & $0.66(1)$ & $4.33(5)$ & 0.005 & -0.003 & 1.812 & 1.034 \\
\hline $\mathrm{O} 2 \cdots \mathrm{H}-\mathrm{O}$ Ser117 & 0.149 & 2.113 & 0.07 & 0.03 & -0.04 & 0.756 & 1.248 \\
\hline
\end{tabular}

Table 7. Reactivity descriptors of the Diclofenac molecule.

\begin{tabular}{|l|c|}
\hline Molecular descriptor & Energy(a.u.) \\
\hline Electron affinity & 0.031 \\
$A=\left[-E_{\text {LUMO }}\right]$ & \\
Ionization potential & 0.213 \\
$I=\left[-E_{\text {HOMO }}\right.$ & \\
Global hardness & \\
$H=(I-A) / 2$ & 0.091 \\
Softness & 5.495 \\
$S=1 / 2 \eta$ & \\
Electronegativity & 0.122 \\
$X=(I+A) / 2$ & \\
Electrophilicity index & \\
$\Omega=\mu^{2} / 2 \eta$ & 0.086 \\
HOMO energy & -0.213 \\
LUMO energy & -0.031 \\
\hline
\end{tabular}


Fig. 1. ORTEP view of the diclofenac molecule, showing the atom-numbering scheme. Displacement ellipsoids are drawn at the $50 \%$ probability level.

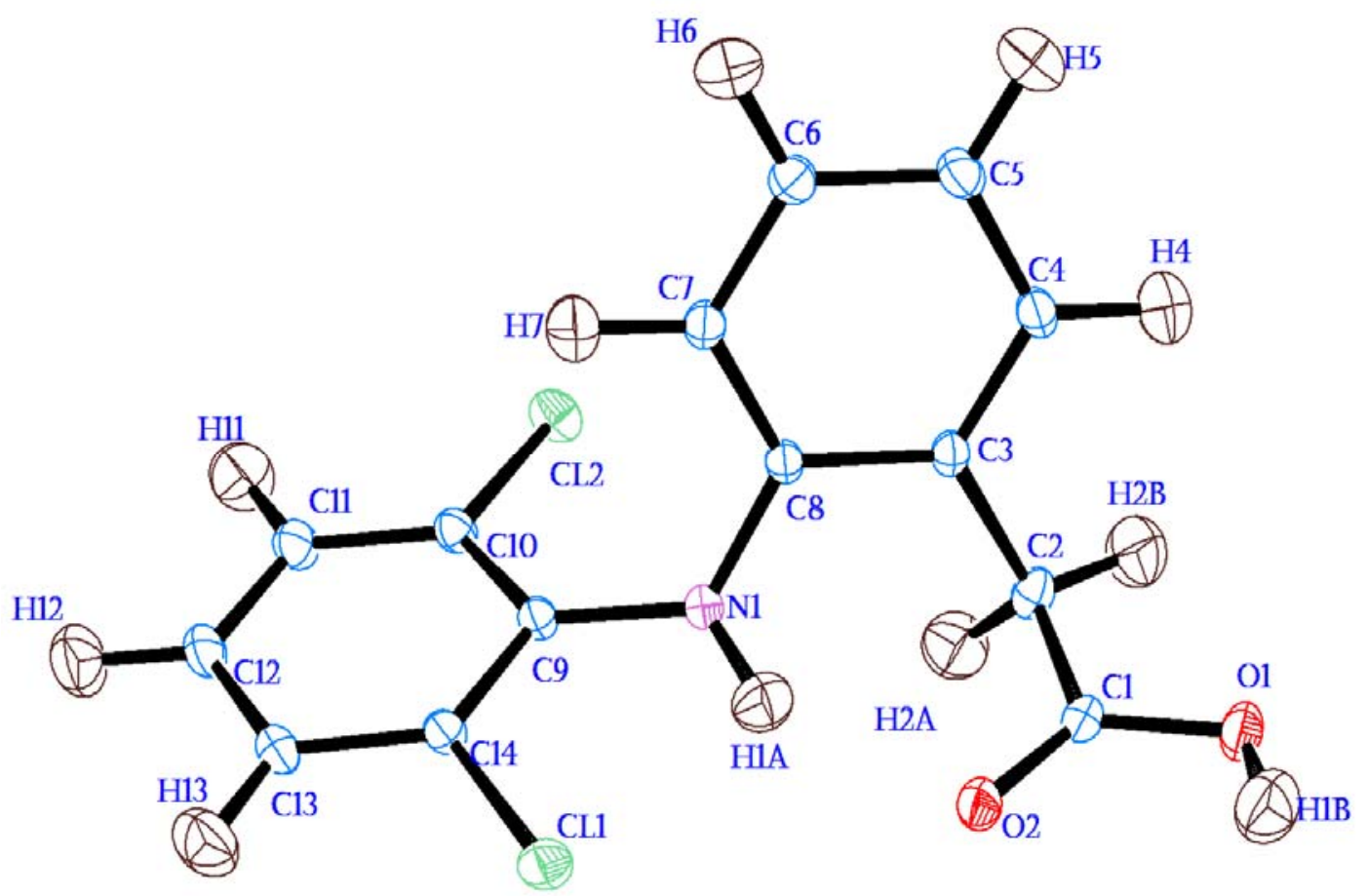

Fig. 2. a) Crystal packing of diclofenac molecule along the $\mathbf{b}$ axis.

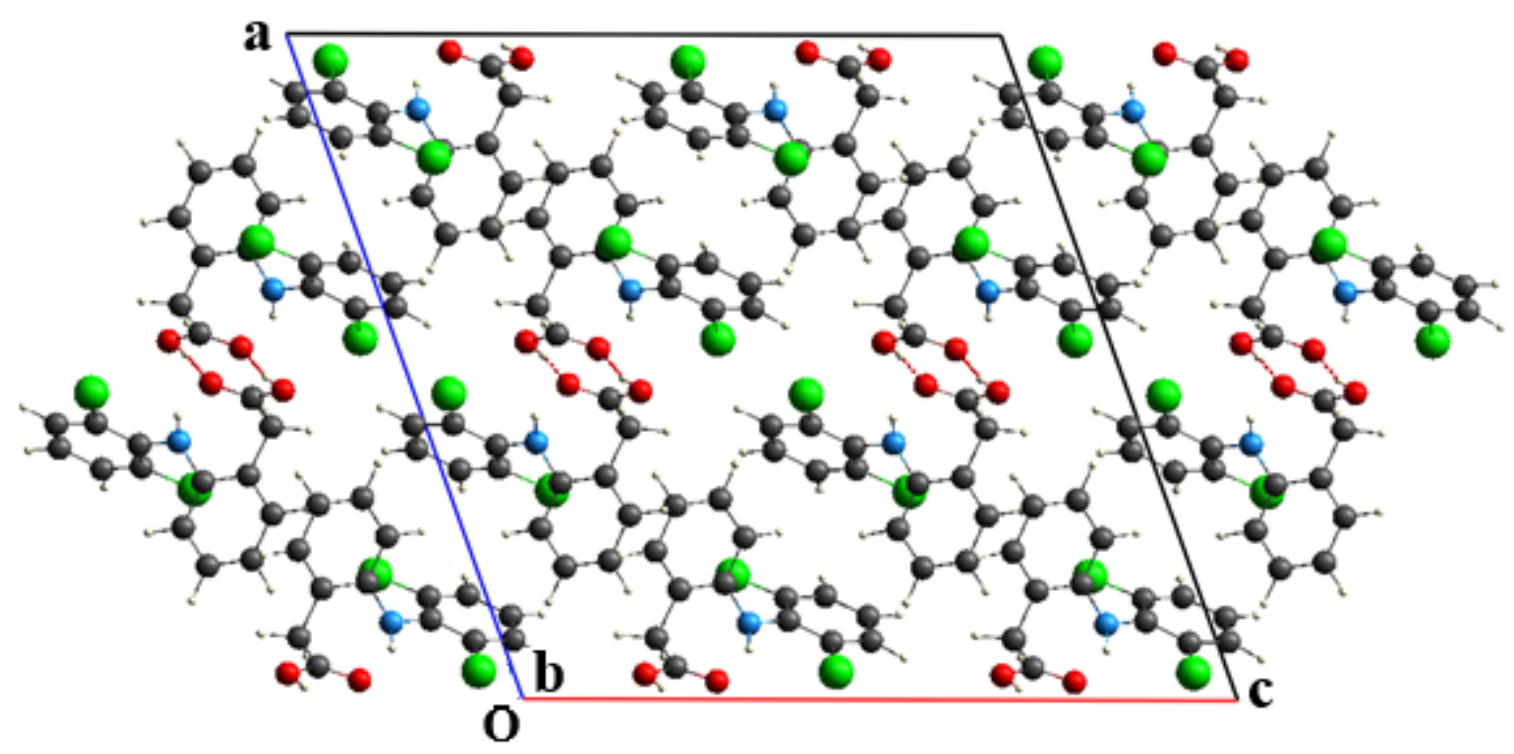


(b) Crystallographic auto stereogram [52] showing translations along the short axis $b=6.89 \AA$

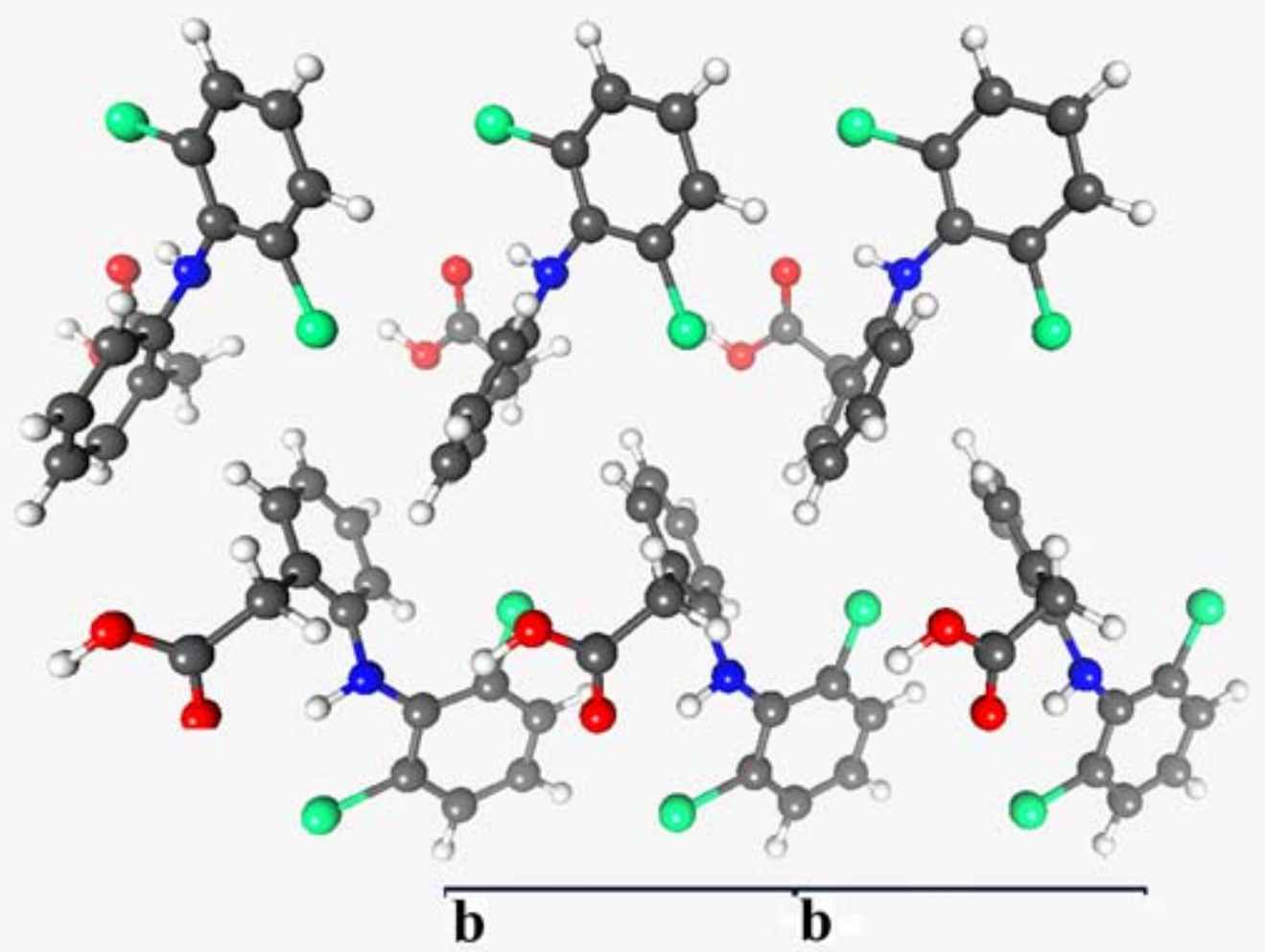

Fig. 3.a) Hirshfeld surface showing the strength of the $\mathrm{COOH}$ homo-synthon interaction in a dimer.

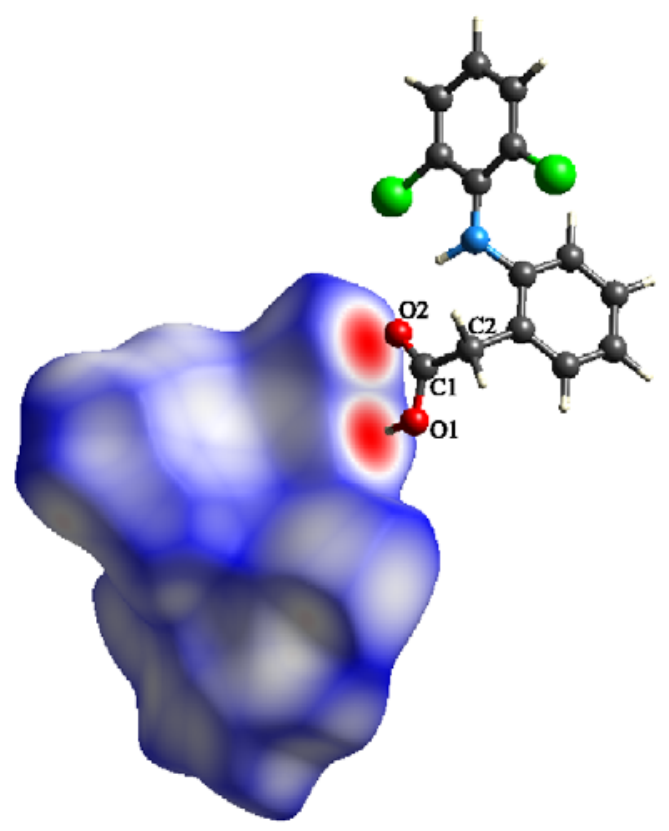


b) View of halogen...halogen type I trans $\mathrm{Cl}$... Cl geometry between two parallel aromatic rings.

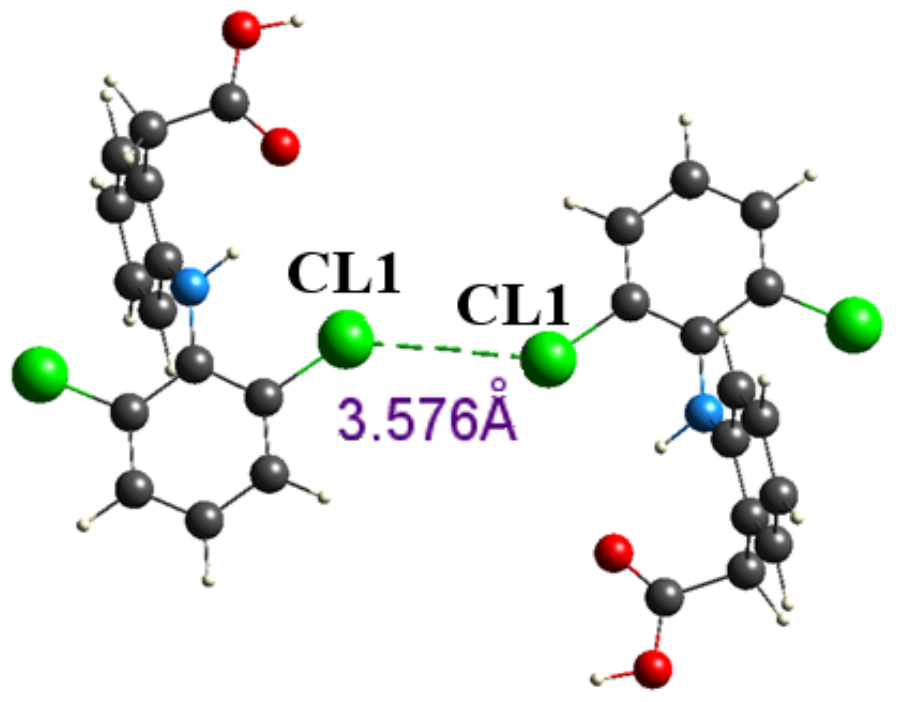

Fig. 4. Fingerprint plots: (a) full, (b) resolved into $\mathrm{H} \cdots \mathrm{H}$ and (c) $\mathrm{Cl} \cdots \mathrm{H} / \mathrm{H} \cdots \mathrm{Cl}$ d) $\mathrm{O} \cdots \mathrm{H} / \mathrm{H} \cdots \mathrm{O}$ contacts, showing the percentages of contact contributing to the total Hirshfeld surface area of the diclofenac molecule in the crystal.

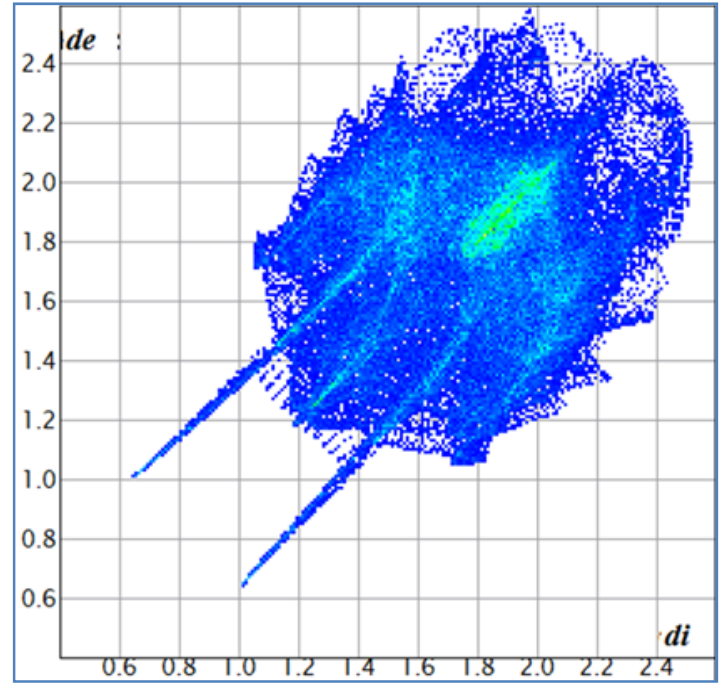

(a)

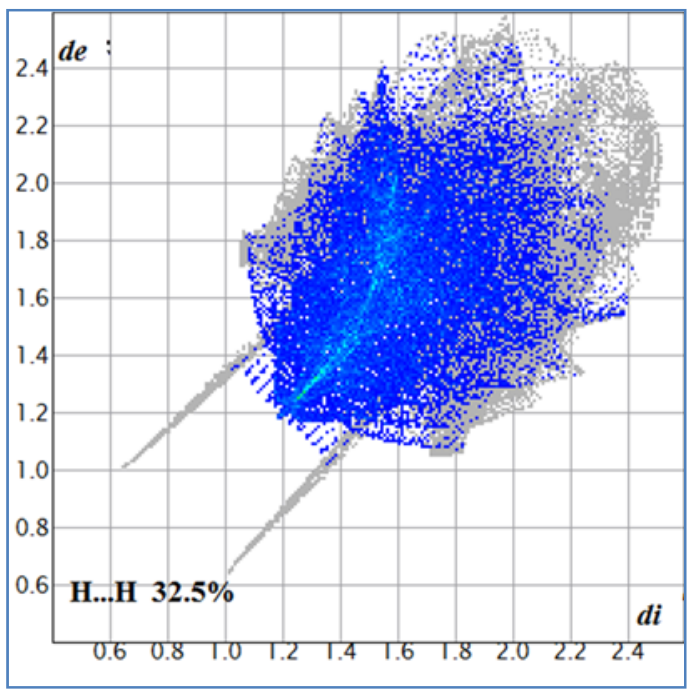

(b) 


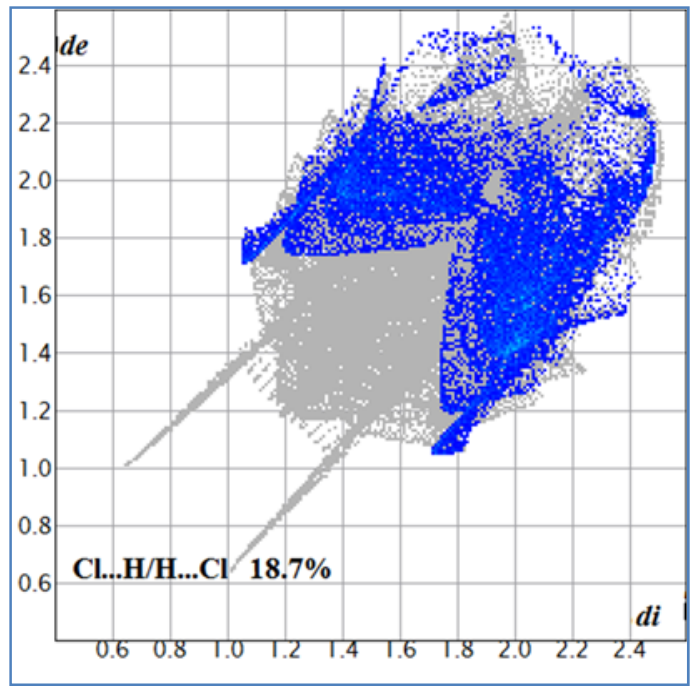

(c)

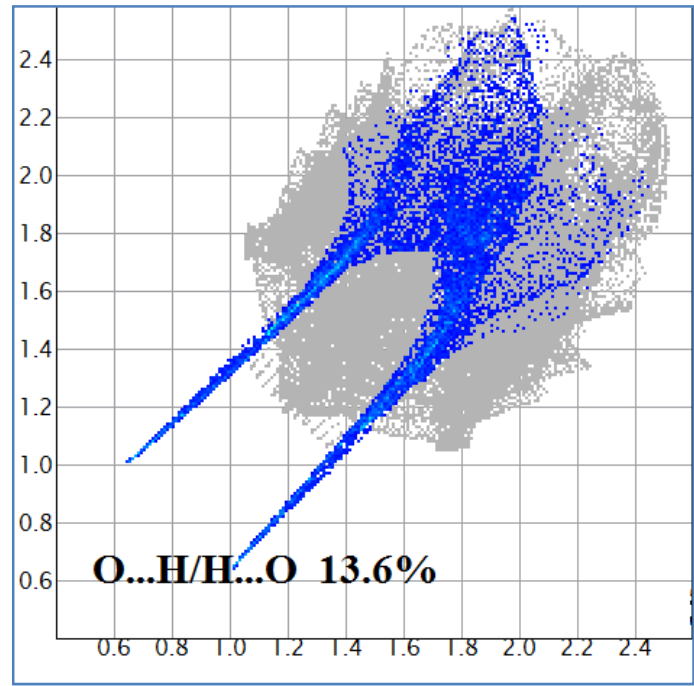

(d)

Fig. 5. Hirshfeld surface coloured according to the interior (a) exterior (b) atom contributing most to the electron density. The view was made with MoPro Viewer. The orientation of the molecule is also shown. Carbon: dark grey, hydrogen Hc: grey, chlorine: green, oxygen: red, polar hydrogen Hp: yellow

(a)

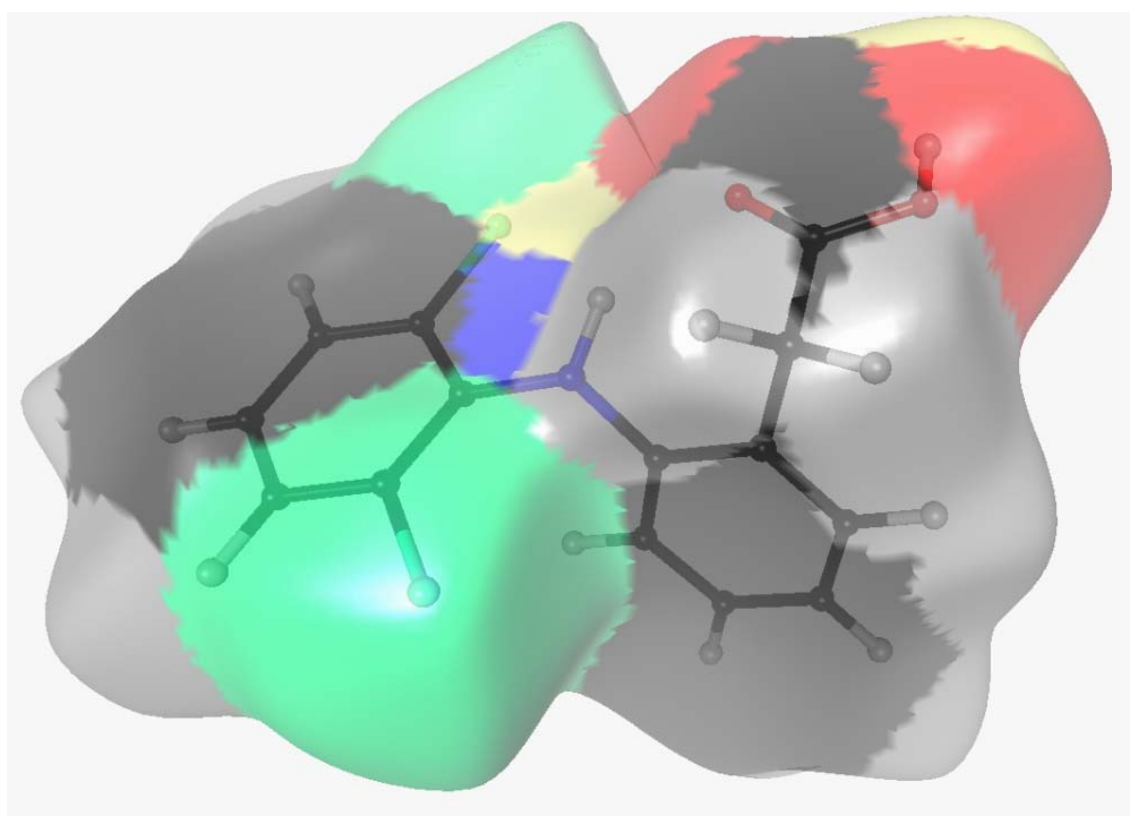


(b)

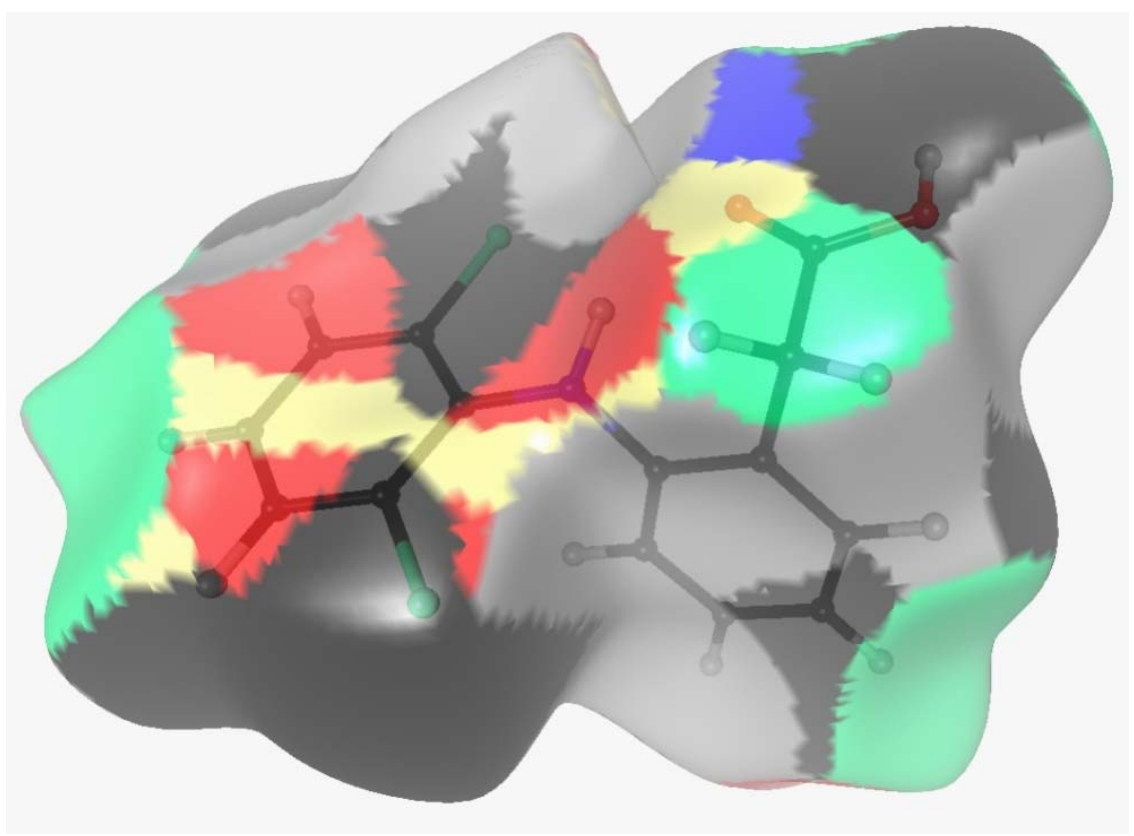

Fig. 6. Residual electron density map of the phenyl ring. Cutoff $I>2 \sigma(I)$, contour $0.05 \mathrm{e} / \AA^{3}$. Blue lines represent positive contours and red lines represent negative contours and the green lines are zero contours.

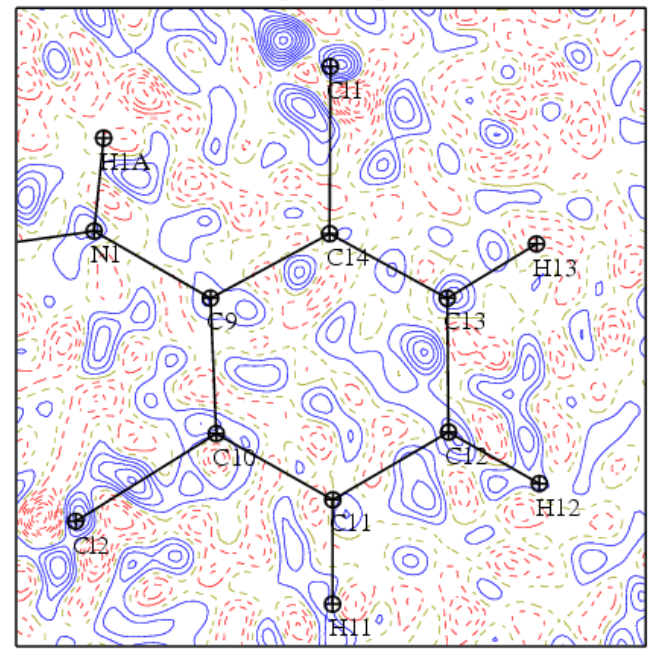


Fig. 7. Deformation electron density map for a) 2, 6-dichlorophenyl and b) Phenyl ring. Contour intervals are $0.05 \mathrm{e}^{-3}$; blue lines are positive contours, red lines are negative contours and green lines are zero contours.

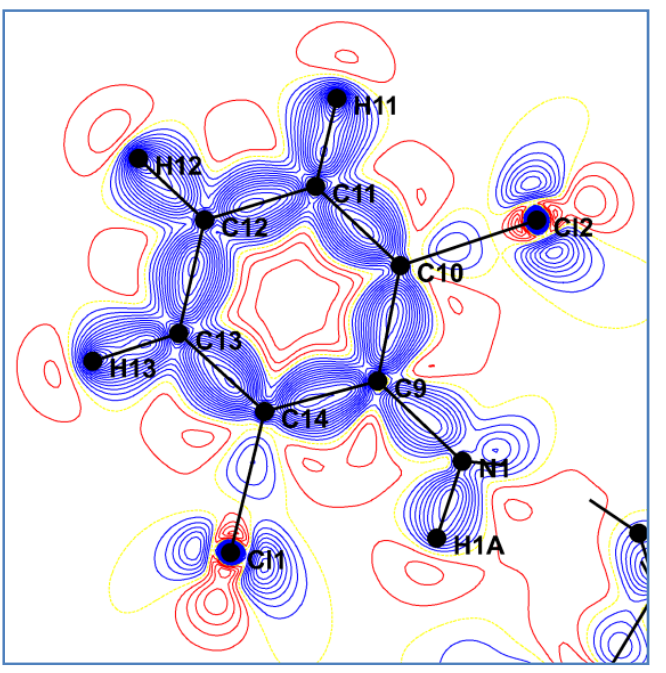

(a)

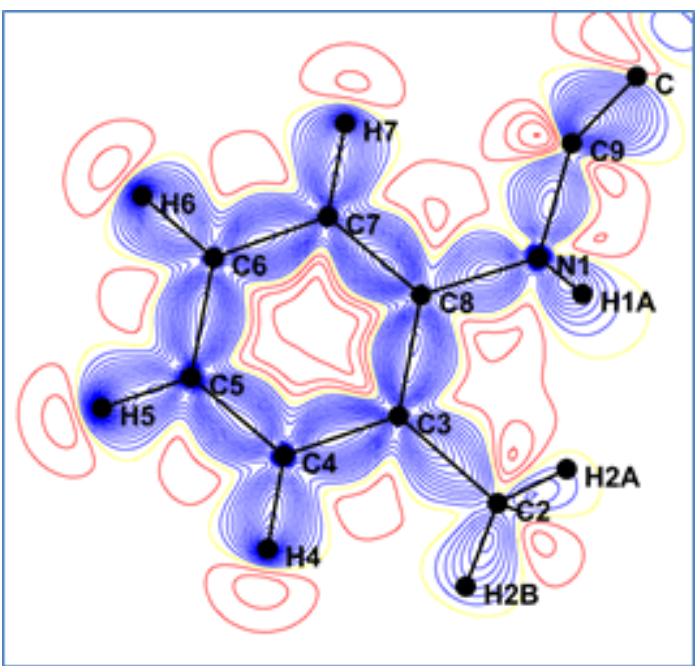

(b) 
Fig. 8. Laplacian of the electron density for the (a) 2,6-dichlorophenyl, (b) Phenyl ring. Solid blue and dotted red lines represent the positive and negative contour lines respectively. Contour levels are $2,4,8,10^{\mathrm{n}}, n=-1,0,1$ The bond critical points positions are shown by black crosses. (c) $3 \mathrm{D}$ view of the Laplacian of total electron density around the N1 atom. Contour level: -40 $\mathrm{e} / \AA^{3}$.

(a)

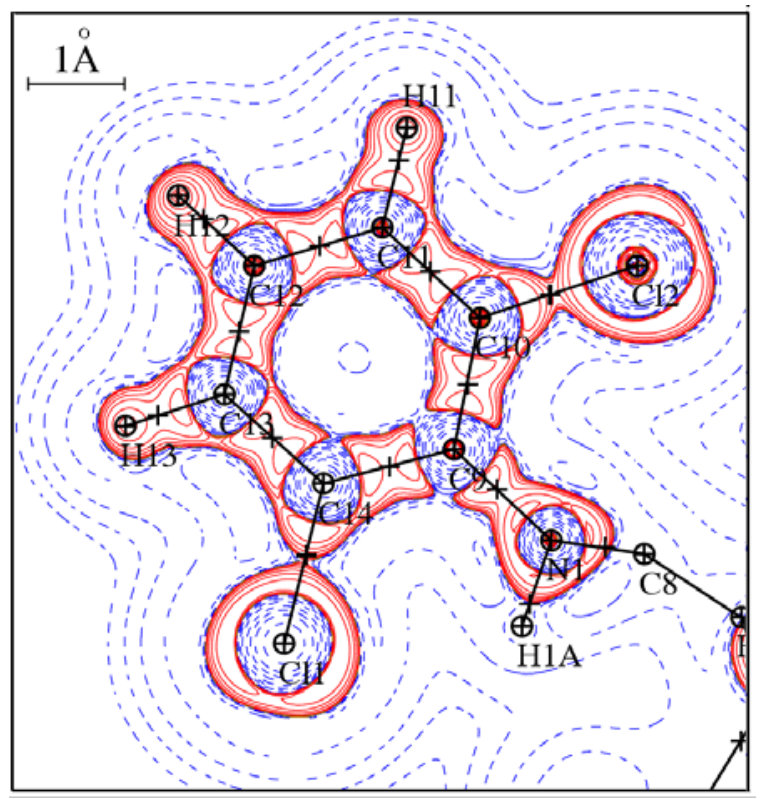

(c)

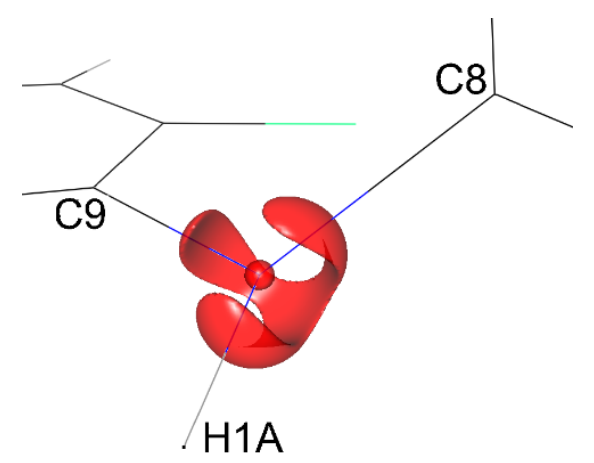

(b)

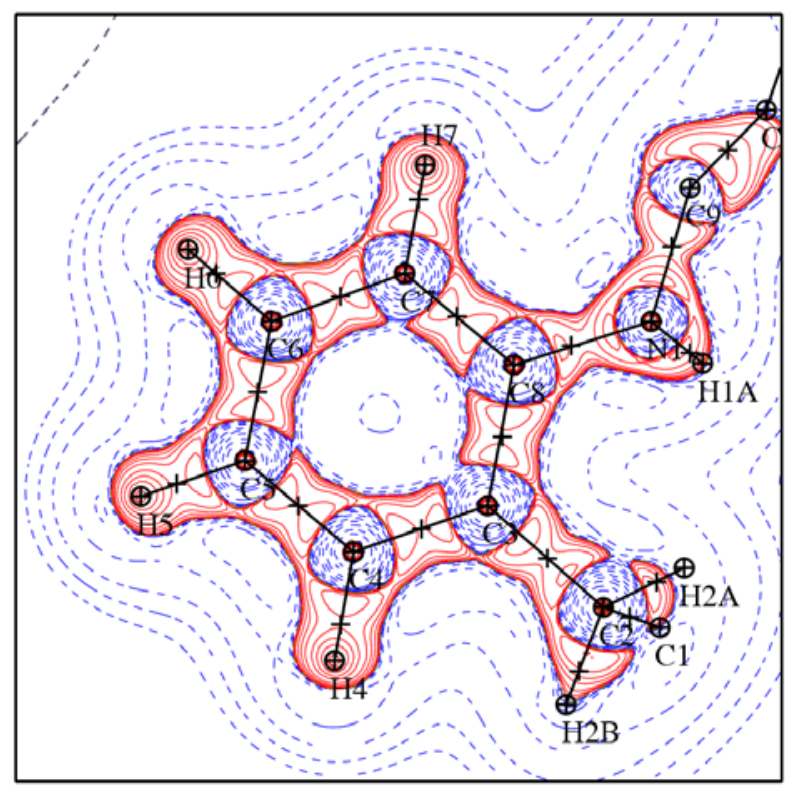


C)

Fig. 9. Electrostatic potential maps. Contour levels, red negative $V=-0.3 \mathrm{eV}$, blue: positive $V=0.5 \mathrm{eV}$ (a) around the diclofenac molecule, (b) around the $\mathrm{O} 1-\mathrm{H} 1 \mathrm{~B} \cdots \mathrm{O} 2$ interaction.

(c) around the interaction between $\mathrm{O} 1-\mathrm{H} 1 \mathrm{~B} \cdots \mathrm{O} 2$ of diclofenac molecule and Ser117 of the transthyretin protein.

(a)

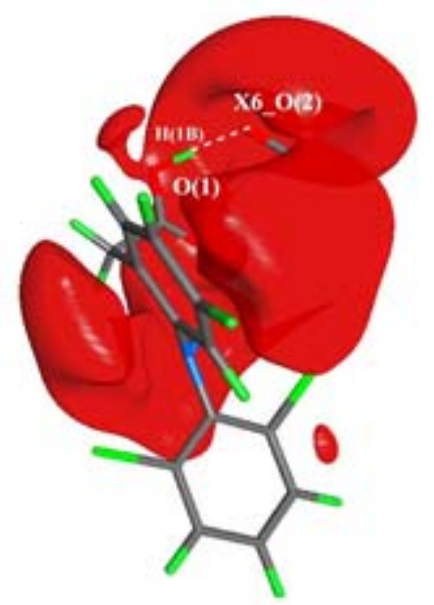

(b)

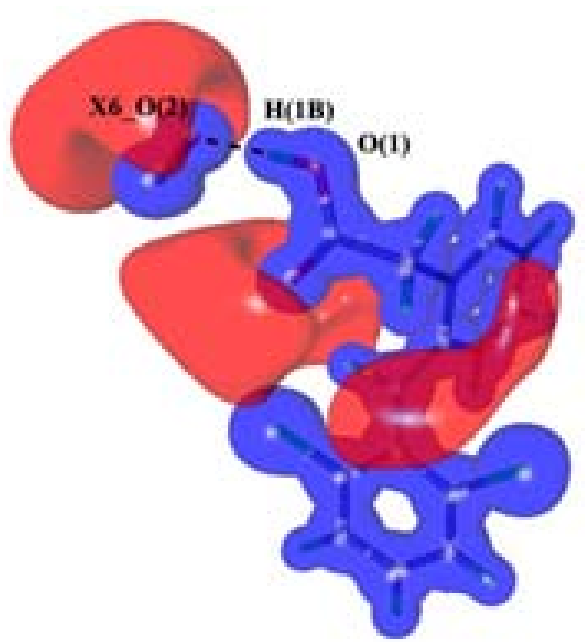


(c)

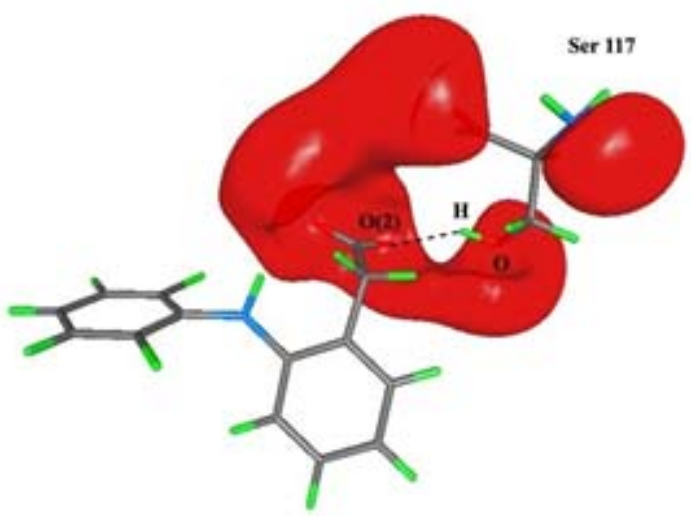

Fig. 10. (a) Laplacian of the electron density of O1-H1B...O2 interaction (b) Relief map (c) Laplacian map of the interaction between O-H of Ser117 and O2. Contour level 2, 4, 8, $10^{\mathrm{n}}, n$ $=-1,0,1$.

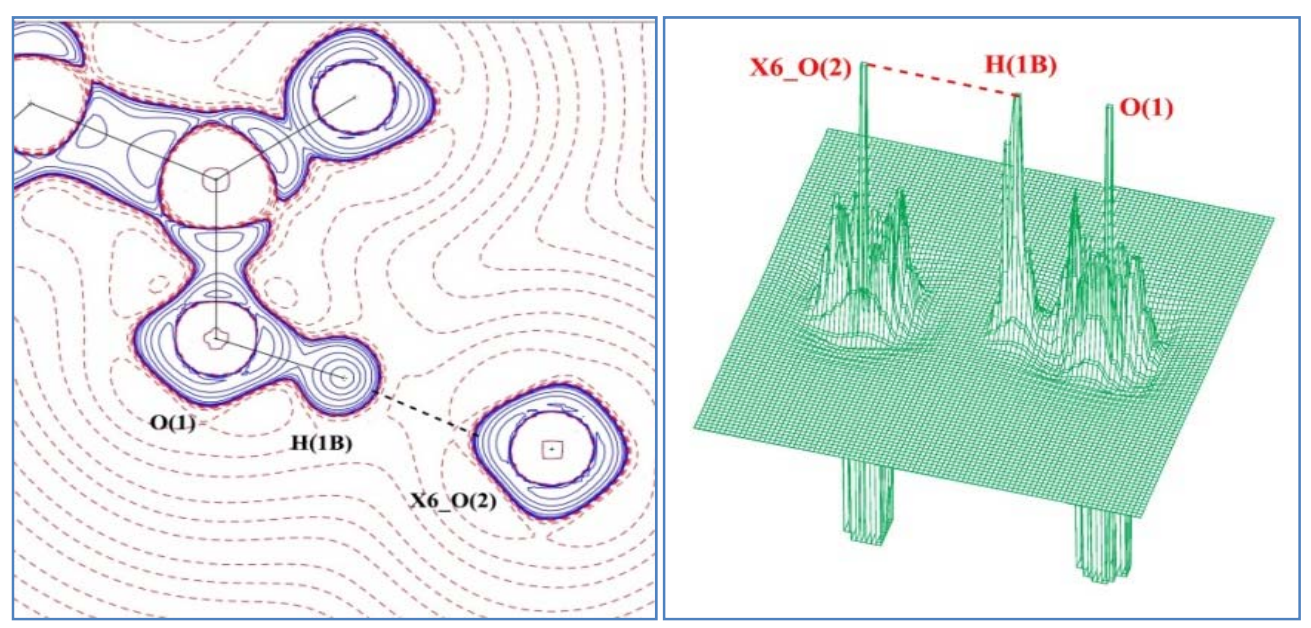

(a)

(b)

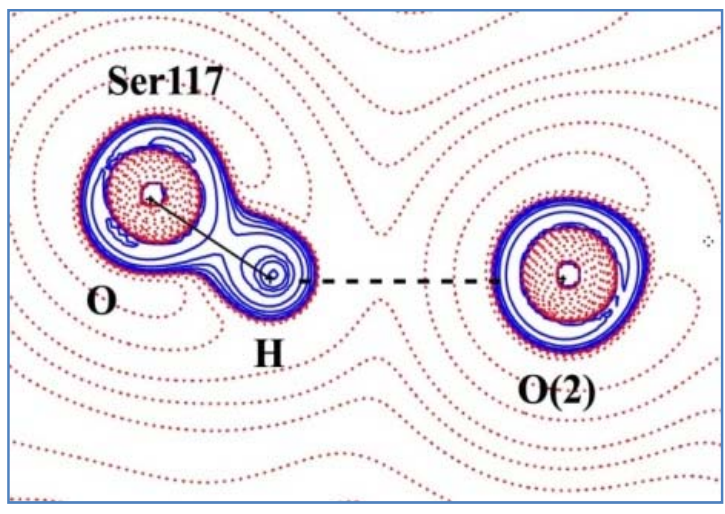

(c) 
Fig. 11.View of the (a) RMSD, (b) RMSF, (c) radius of gyration and (d) number of hydrogen bonding present in the human transthyretin enzyme.

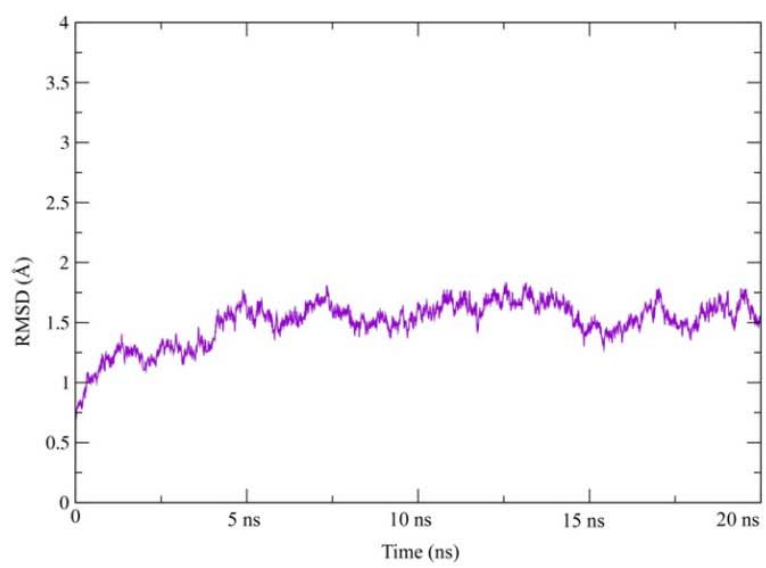

(a)

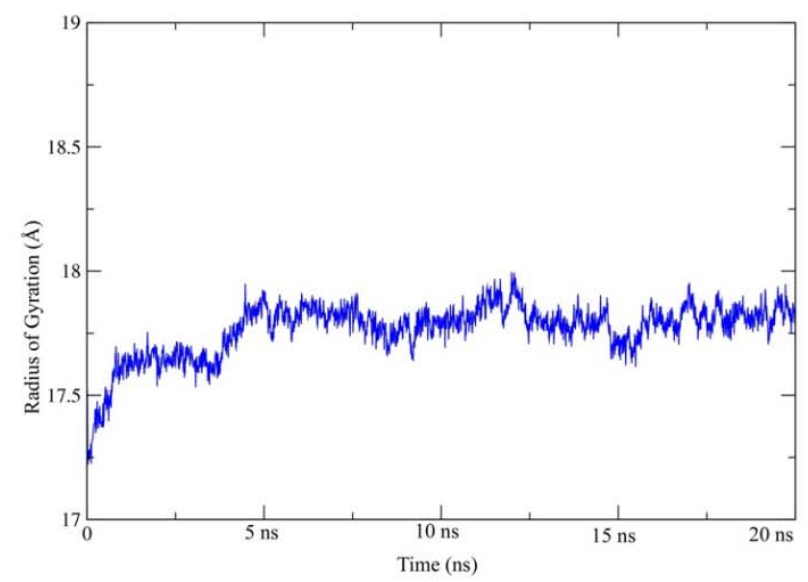

(c)

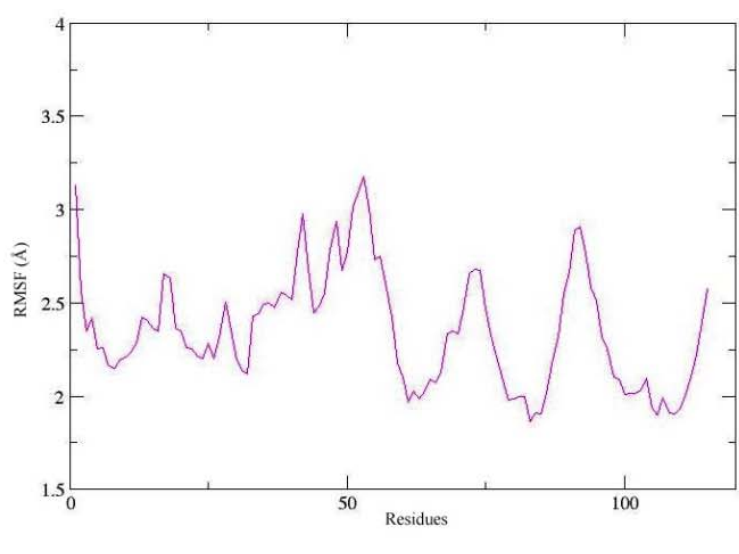

(b)

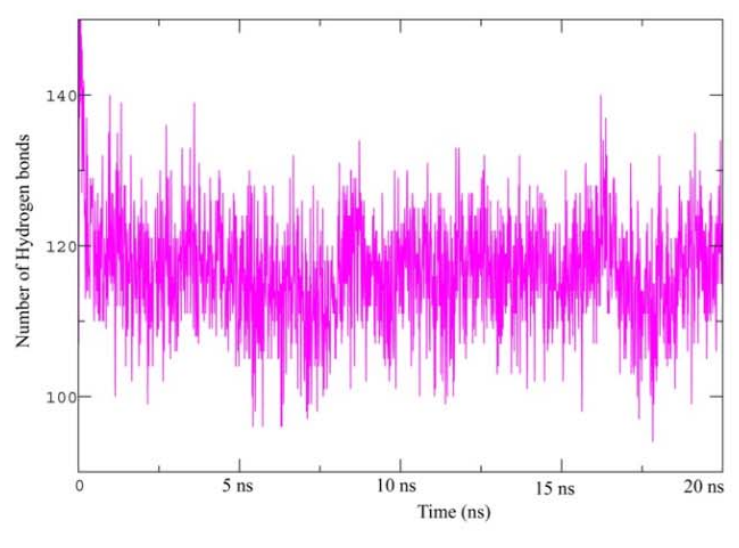

(d) 
Fig.12. The diclofenac molecule at the binding site of human transthyretin enzyme in different views.

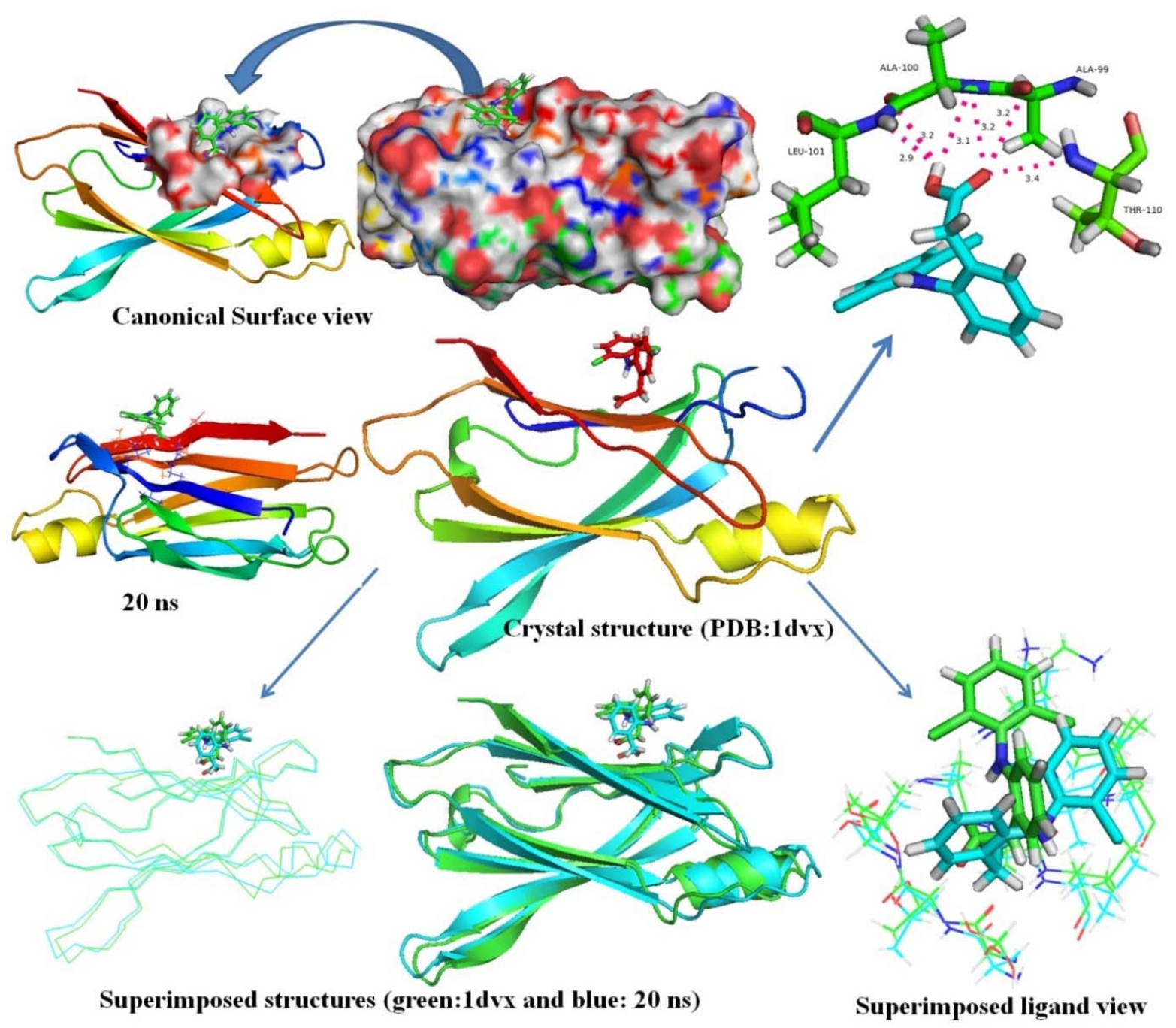




\section{References}

[1] T. Yamazaki, M. Muramoto, T. Oe, N. Morikawa, O. Okitsu, T. Nagashima, S. Nishimura, Y. Katayama, Y. Kita, Diclofenac, a non-steroidal anti-inflammatory drug, suppresses apoptosis induced by endoplasmic reticulum stresses by inhibiting caspase signaling, Neuropharmacology. 50 (2006) 558-567. doi:10.1016/j.neuropharm.2005.10.016.

[2] B. Hinz, T. Rau, D. Auge, U. Werner, R. Ramer, S. Rietbrock, K. Brune, Aceclofenac spares cyclooxygenase 1 as a result of limited but sustained biotransformation to diclofenac, Clin. Pharmacol. Ther. (2003). doi:10.1016/S0009-9236(03)00167-X.

[3] S. Connelly, S. Choi, S.M. Johnson, J.W. Kelly, I.A. Wilson, Structure-based design of kinetic stabilizers that ameliorate the transthyretin amyloidoses, Curr. Opin. Struct. Biol. (2010). doi:10.1016/j.sbi.2009.12.009.

[4] L.M.T.R. Lima, V. de A. Silva, L. de C. Palmieri, M.C.B.R. Oliveira, D. Foguel, I. Polikarpov, Identification of a novel ligand binding motif in the transthyretin channel, Bioorganic Med. Chem. (2010). doi:10.1016/j.bmc.2009.11.025.

[5] V. López-Mejías, J.W. Kampf, A.J. Matzger, Nonamorphism in flufenamic acid and a new record for a polymorphic compound with solved structures, J. Am. Chem. Soc. (2012). doi:10.1021/ja302601f.

[6] V.B. Oza, C. Smith, P. Raman, E.K. Koepf, H.A. Lashuel, H.M. Petrassi, K.P. Chiang, E.T. Powers, J. Sachettinni, J.W. Kelly, Synthesis, structure, and activity of diclofenac analogues as transthyretin amyloid fibril formation inhibitors, J. Med. Chem. (2002). doi:10.1021/jm010257n.

[7] P. Macchi, H.-B. Bürgi, A.S. Chimpri, J. Hauser, Z. Gál, Low-energy contamination of Mo microsource X-ray radiation: analysis and solution of the problem, J. Appl. Crystallogr. 44 (2011) 763-771. doi:10.1107/s0021889811016232.

[8] Oxford Diffraction Ltd., CrysAlisPro, CrysAlisPro. (2010).

[9] C. Jelsch, B. Guillot, A. Lagoutte, C. Lecomte, Advances in protein and smallmolecule charge-density refinement methods usingMoPro, J. Appl. Crystallogr. 38 
(2005) 38-54. doi:10.1107/s0021889804025518.

[10] N.K. Hansen, P. Coppens, Testing aspherical atom refinements on small-molecule data sets, Acta Crystallogr. Sect. A. 34 (1978) 909-921. doi:10.1107/s0567739478001886.

[11] Z. Su, P. Coppens, Relativistic X-ray Elastic Scattering Factors for Neutral AtomsZ= $1-54$ from Multiconfiguration Dirac-Fock Wavefunctions in the $0-12 \AA-1 \sin \theta / \lambda$ Range, and Six-Gaussian Analytical Expressions in the 0-6̊-1Range, Acta Crystallogr. Sect. A Found. Crystallogr. 53 (1997) 749-762. doi:10.1107/s0108767397004558.

[12] E. Koch, Twinning, Int. Tables Crystallogr. (2006) 10-14. doi:10.1107/97809553602060000574.

[13] A.Ø. Madsen, A.A. Hoser, SHADE3server: a streamlined approach to estimate H-atom anisotropic displacement parameters using periodicab initiocalculations or experimental information, J. Appl. Crystallogr. 47 (2014) 2100-2104. doi:10.1107/s1600576714022973.

[14] F.H. Allen, O. Kennard, D.G. Watson, L. Brammer, A.G. Orpen, R. Taylor, Tables of bond lengths determined by x-ray and neutron diffraction. Part 1. Bond lengths in organic compounds, J. Chem. Soc. Perkin Trans. 2. (1987). doi:10.1039/P298700000S1.

[15] B. Zarychta, J. Zaleski, J. Kyzioł, Z. Daszkiewicz, C. Jelsch, Charge-density analysis of 1-nitroindoline: refinement quality using freeRfactors and restraints, Acta Crystallogr. Sect. B Struct. Sci. 67 (2011) 250-262. doi:10.1107/s0108768111013140.

[16] V. V Zhurov, E.A. Zhurova, A.A. Pinkerton, Optimization and evaluation of data quality for charge density studies, J. Appl. Crystallogr. 41 (2008) 340-349. doi:10.1107/s0021889808004482.

[17] K. Meindl, J. Henn, Foundations of residual-density analysis, Acta Crystallogr. Sect. A Found. Crystallogr. 64 (2008) 404-418. doi:10.1107/s0108767308006879.

[18] M.J. Frisch, G.W. Trucks, H.B. Schlegel, G.E. Scuseria, M.A. Robb, J.R. Cheeseman, G. Scalmani, V. Barone, B. Mennucci, G.A. Petersson, H. Nakatsuji, M. Caricato, X. 
Li, H.P. Hratchian, A.F. Izmaylov, J. Bloino, G. Zheng, J.L. Sonnenberg, M. Hada, M. Ehara, K. Toyota, R. Fukuda, J. Hasegawa, M. Ishida, T. Nakajima, Y. Honda, O. Kitao, H. Nakai, T. Vreven, J.A. Montgomery Jr., J.E. Peralta, F. Ogliaro, M. Bearpark, J.J. Heyd, E. Brothers, K.N. Kudin, V.N. Staroverov, R. Kobayashi, J. Normand, K. Raghavachari, A. Rendell, J.C. Burant, S.S. Iyengar, J. Tomasi, M. Cossi, N. Rega, J.M. Millam, M. Klene, J.E. Knox, J.B. Cross, V. Bakken, C. Adamo, J. Jaramillo, R. Gomperts, R.E. Stratmann, O. Yazyev, A.J. Austin, R. Cammi, C. Pomelli, J.W. Ochterski, R.L. Martin, K. Morokuma, V.G. Zakrzewski, G.A. Voth, P. Salvador, J.J. Dannenberg, S. Dapprich, A.D. Daniels, Farkas, J.B. Foresman, J. V Ortiz, J. Cioslowski, D.J. Fox, Gaussian09 Revision D.01, Gaussian Inc. Wallingford CT, Gaussian 09 Revis. C.01. (2010). doi:10.1017/CBO9781107415324.004.

[19] F.B. König, J. Schönbohm, D. Bayles, AIM2000-a program to analyze and visualize atoms in molecules, J. Comput. Chem. (2001). doi:10.1002/1096-987X(20010415)22.

[20] W.L. Jorgensen, J. Chandrasekhar, J.D. Madura, R.W. Impey, M.L. Klein, Comparison of simple potential functions for simulating liquid water, J. Chem. Phys. 79 (1983) 926-935. doi:10.1063/1.445869.

[21] A. Jones, B. Leimkuhler, Adaptive stochastic methods for sampling driven molecular systems, J. Chem. Phys. 135 (2011) 84125. doi:10.1063/1.3626941.

[22] H.J.C. Berendsen, J.P.M. Postma, W.F. van Gunsteren, A. DiNola, J.R. Haak, Molecular dynamics with coupling to an external bath, J. Chem. Phys. 81 (1984) 3684-3690. doi:10.1063/1.448118.

[23] J.C. Phillips, R. Braun, W. Wang, J. Gumbart, E. Tajkhorshid, E. Villa, C. Chipot, R.D. Skeel, L. Kalé, K. Schulten, Scalable molecular dynamics with NAMD, J. Comput. Chem. 26 (2005) 1781-1802. doi:10.1002/jcc.20289.

[24] W. Humphrey, A. Dalke, K. Schulten, VMD: Visual molecular dynamics, J. Mol. Graph. 14 (1996) 33-38. doi:10.1016/0263-7855(96)00018-5.

[25] D.R. Roe, T.E. Cheatham, PTRAJ and CPPTRAJ: Software for Processing and Analysis of Molecular Dynamics Trajectory Data, J. Chem. Theory Comput. 9 (2013) 3084-3095. doi:10.1021/ct400341p. 
[26] N. Muangsin, M. Prajuabsook, P. Chimsook, N. Chantarasiri, K. Siraleartmukul, N. Chaichit, S. Hannongbua, Structure determination of diclofenac in a diclofenaccontaining chitosan matrix using conventional X-ray powder diffraction data, J. Appl. Crystallogr. 37 (2004) 288-294. doi:10.1107/s0021889804002353.

[27] L. Fábián, N. Hamill, K.S. Eccles, H.A. Moynihan, A.R. Maguire, L. McCausland, S.E. Lawrence, Cocrystals of fenamic acids with nicotinamide, Cryst. Growth Des. (2011). doi:10.1021/cg200429j.

[28] J.J. McKinnon, M.A. Spackman, A.S. Mitchell, Novel tools for visualizing and exploring intermolecular interactions in molecular crystals, Acta Crystallogr. Sect. B Struct. Sci. 60 (2004) 627-668. doi:10.1107/s0108768104020300.

[29] M.A. Spackman, P.G. Byrom, A novel definition of a molecule in a crystal, Chem. Phys. Lett. 267 (1997) 215-220. doi:10.1016/s0009-2614(97)00100-0.

[30] V.R. Hathwar, T.N.G. Row, Nature of $\mathrm{Cl} \cdots \mathrm{Cl}$ Intermolecular Interactions via Experimental and Theoretical Charge Density Analysis: Correlation of Polar Flattening Effects with Geometry, J. Phys. Chem. A. 114 (2010) 13434-13441. doi:10.1021/jp1100413.

[31] M.A. Spackman, From charge densities to crystal engineering, Zeitschrift Für Krist. Cryst. Mater. 217 (2002). doi:10.1524/zkri.217.7.369.23709.

[32] C. Jelsch, K. Ejsmont, L. Huder, The enrichment ratio of atomic contacts in crystals, an indicator derived from the Hirshfeld surface analysis, IUCrJ. 1 (2014) 119-128. doi:10.1107/s2052252514003327.

[33] B. Guillot, MoProViewer: a molecule viewer for theMoProcharge-density analysis program, Acta Crystallogr. Sect. A Found. Crystallogr. 68 (2012) s204-s204. doi:10.1107/s0108767312096067.

[34] K. Eskandari, H. Zariny, Halogen bonding: A lump-hole interaction, Chem. Phys. Lett. 492 (2010) 9-13. doi:10.1016/j.cplett.2010.04.021.

[35] V.R. Hathwar, R.G. Gonnade, P. Munshi, M.M. Bhadbhade, T.N.G. Row, Halogen bonding in 2,5-dichloro-1,4-benzoquinone: Insights from experimental and theoretical 
charge density analysis, Cryst. Growth Des. (2011). doi:10.1021/cg2000415.

[36] K. Saravanan, C. Kalaiarasi, P. Kumaradhas, Understanding the conformational flexibility and electrostatic properties of curcumin in the active site of rhAChE via molecular docking, molecular dynamics, and charge density analysis, J. Biomol. Struct. Dyn. 35 (2017) 3627-3647. doi:10.1080/07391102.2016.1264891.

[37] K. Saravanan, M. Sivanandam, G. Hunday, L. Mathiyalagan, P. Kumaradhas, Investigation of intermolecular interactions and stability of verubecestat in the active site of BACE1: Development of first model from QM/MM-based charge density and MD analysis, J. Biomol. Struct. Dyn. (2018) 1-16. doi:10.1080/07391102.2018.1479661.

[38] D.S. Arputharaj, V.R. Hathwar, T.N. Guru Row, P. Kumaradhas, Topological Electron Density Analysis and Electrostatic Properties of Aspirin: An Experimental and Theoretical Study, Cryst. Growth Des. 12 (2012) 4357-4366. doi:10.1021/cg300269n.

[39] G. Rajalakshmi, V.R. Hathwar, P. Kumaradhas, Topological analysis of electron density and the electrostatic properties of isoniazid: an experimental and theoretical study, Acta Crystallogr. Sect. B Struct. Sci. Cryst. Eng. Mater. 70 (2014) 331-341. doi:10.1107/s2052520613033209.

[40] E.A. Zhurova, V. V Zhurov, P. Kumaradhas, S. Cenedese, A.A. Pinkerton, Charge Density and Electrostatic Potential Study of $16 \alpha, 17 \beta$-Estriol and the Binding of Estrogen Molecules to the Estrogen Receptors ER $\alpha$ and ER $\beta$, J. Phys. Chem. B. 120 (2016) 8882-8891. doi:10.1021/acs.jpcb.6b05961.

[41] L.-C. Wu, W.-C. Chung, C.-C. Wang, G.-H. Lee, S.-I. Lu, Y. Wang, A charge density study of $\pi$-delocalization and intermolecular interactions, Phys. Chem. Chem. Phys. 17 (2015) 14177-14184. doi:10.1039/c5cp01575h.

[42] D.E. Hibbs, J. Overgaard, R.O. Piltz, X-N Charge density analysis of the hydrogen bonding motif in 1-(2-hydroxy-5-nitrophenyl)ethanoneElectronic supplementary information (ESI) available: multipole population coefficients and pseudoatom parameterization. See http://www.rsc.org/suppdata/ob/b2/, Org. Biomol. Chem. 1 (2003) 1191-1198. doi:10.1039/b211683a. 
[43] R.F.W. Bader, H. Essén, The characterization of atomic interactions, J. Chem. Phys. 80 (1984) 1943-1960. doi:10.1063/1.446956.

[44] Y.A. Abramov, On the Possibility of Kinetic Energy Density Evaluation from the Experimental Electron-Density Distribution, Acta Crystallogr. Sect. A Found. Crystallogr. 53 (1997) 264-272. doi:10.1107/s010876739601495x.

[45] E. Espinosa, E. Molins, C. Lecomte, Hydrogen bond strengths revealed by topological analyses of experimentally observed electron densities, Chem. Phys. Lett. 285 (1998) 170-173. doi:10.1016/s0009-2614(98)00036-0.

[46] U. Sarkar, J. Padmanabhan, R. Parthasarathi, V. Subramanian, P.K. Chattaraj, Toxicity analysis of polychlorinated dibenzofurans through global and local electrophilicities, J. Mol. Struct. THEOCHEM. 758 (2006) 119-125. doi:10.1016/j.theochem.2005.10.021.

[47] U.D. Priyakumar, G.N. Sastry, Theoretical Study of Silabenzene and Its Valence Isomers, Organometallics. 21 (2002) 1493-1499. doi:10.1021/om011001i.

[48] R. Ghiasi, A computational study of the arsabenzenes: Structure, properties and aromaticity, J. Organomet. Chem. 690 (2005) 4761-4767. doi:10.1016/j.jorganchem.2005.07.069.

[49] The nature of the chemical bond and the structure of molecules and crystals, by Linus Pauling. 2nd Edition. xvi + 450 pages. Cornell University Press, Ithaca, N. Y., 1940. Price, \$4.50, J. Am. Pharm. Assoc. (Scientific Ed.). 30 (1941) 30. doi:10.1002/jps.3030300111.

[50] R.G. Parr, L. v. Szentpály, S. Liu, Electrophilicity Index, J. Am. Chem. Soc. 121 (1999) 1922-1924. doi:10.1021/ja983494x.

[51] K.K. Hazarika, N.C. Baruah, R.C. Deka, Molecular structure and reactivity of antituberculosis drug molecules isoniazid, pyrazinamide, and 2methylheptylisonicotinate: a density functional approach, Struct. Chem. 20 (2009) 1079-1085. doi:10.1007/s11224-009-9512-2.

[52] A. Katrusiak, Crystallographic autostereograms, J. Mol. Graph. Model. (2001). doi:10.1016/S1093-3263(00)00085-1. 


\section{Supporting information}

Table Sup 1: Selected geometric parameters $\left(\AA,{ }^{\circ}\right)$

\begin{tabular}{|c|c|c|c|}
\hline $\mathrm{C} 11-\mathrm{C} 14$ & $1.7366(4)$ & $\mathrm{C} 4-\mathrm{C} 5$ & $1.3921(6)$ \\
\hline $\mathrm{Cl} 2-\mathrm{C} 10$ & $1.7249(4)$ & $\mathrm{C} 5-\mathrm{C} 6$ & $1.3905(6)$ \\
\hline $\mathrm{O} 1-\mathrm{C} 1$ & $1.3080(8)$ & $\mathrm{C} 6-\mathrm{C} 7$ & $1.3919(6)$ \\
\hline $\mathrm{O} 2-\mathrm{C} 1$ & $1.2314(6)$ & $\mathrm{C} 7-\mathrm{C} 8$ & $1.3977(5)$ \\
\hline $\mathrm{N} 1-\mathrm{C} 9$ & $1.3939(5)$ & $\mathrm{C} 9-\mathrm{C} 14$ & $1.4045(6)$ \\
\hline $\mathrm{N} 1-\mathrm{C} 8$ & $1.4141(5)$ & $\mathrm{C} 9-\mathrm{C} 10$ & $1.4069(5)$ \\
\hline $\mathrm{C} 1-\mathrm{C} 2$ & $1.5072(6)$ & $\mathrm{C} 10-\mathrm{C} 11$ & $1.3894(6)$ \\
\hline $\mathrm{C} 2-\mathrm{C} 3$ & $1.5135(6)$ & $\mathrm{C} 11-\mathrm{C} 12$ & $1.3902(7)$ \\
\hline $\mathrm{C} 3-\mathrm{C} 4$ & $1.3933(6)$ & $\mathrm{C} 12-\mathrm{C} 13$ & $1.3900(6)$ \\
\hline $\mathrm{C} 3-\mathrm{C} 8$ & $1.4066(5)$ & $\mathrm{C} 13-\mathrm{C} 14$ & $1.3902(6)$ \\
\hline $\mathrm{C} 9-\mathrm{N} 1-\mathrm{C} 8$ & $122.73(3)$ & $\mathrm{C} 3-\mathrm{C} 8-\mathrm{N} 1$ & $118.19(3)$ \\
\hline $\mathrm{O} 2-\mathrm{C} 1-\mathrm{O} 1$ & $123.67(5)$ & $\mathrm{N} 1-\mathrm{C} 9-\mathrm{C} 14$ & $121.47(3)$ \\
\hline $\mathrm{O} 2-\mathrm{C} 1-\mathrm{C} 2$ & $121.62(4)$ & $\mathrm{N} 1-\mathrm{C} 9-\mathrm{C} 10$ & $122.36(3)$ \\
\hline $\mathrm{O} 1-\mathrm{C} 1-\mathrm{C} 2$ & $114.70(4)$ & $\mathrm{C} 14-\mathrm{C} 9-\mathrm{C} 10$ & $115.99(3)$ \\
\hline $\mathrm{C} 1-\mathrm{C} 2-\mathrm{C} 3$ & $110.08(3)$ & $\mathrm{C} 11-\mathrm{C} 10-\mathrm{C} 9$ & $122.02(3)$ \\
\hline $\mathrm{C} 4-\mathrm{C} 3-\mathrm{C} 8$ & $119.58(3)$ & $\mathrm{C} 11-\mathrm{C} 10-\mathrm{Cl} 2$ & $120.02(4)$ \\
\hline $\mathrm{C} 4-\mathrm{C} 3-\mathrm{C} 2$ & $119.82(3)$ & $\mathrm{C} 9-\mathrm{C} 10-\mathrm{Cl} 2$ & $119.55(3)$ \\
\hline $\mathrm{C} 8-\mathrm{C} 3-\mathrm{C} 2$ & $120.60(3)$ & $\mathrm{C} 12-\mathrm{C} 11-\mathrm{C} 10$ & $120.02(4)$ \\
\hline $\mathrm{C} 5-\mathrm{C} 4-\mathrm{C} 3$ & $120.97(3)$ & $\mathrm{C} 13-\mathrm{C} 12-\mathrm{C} 11$ & $119.78(4)$ \\
\hline $\mathrm{C} 6-\mathrm{C} 5-\mathrm{C} 4$ & $119.27(4)$ & $\mathrm{C} 12-\mathrm{C} 13-\mathrm{C} 14$ & $119.33(3)$ \\
\hline $\mathrm{C} 5-\mathrm{C} 6-\mathrm{C} 7$ & $120.54(4)$ & $\mathrm{C} 13-\mathrm{C} 14-\mathrm{C} 9$ & $122.75(3)$ \\
\hline $\mathrm{C} 6-\mathrm{C} 7-\mathrm{C} 8$ & $120.33(3)$ & $\mathrm{C} 13-\mathrm{C} 14-\mathrm{Cl1}$ & $118.59(3)$ \\
\hline $\mathrm{C} 7-\mathrm{C} 8-\mathrm{C} 3$ & $119.30(3)$ & $\mathrm{C} 9-\mathrm{C} 14-\mathrm{Cl1}$ & $118.66(3)$ \\
\hline $\mathrm{C} 7-\mathrm{C} 8-\mathrm{N} 1$ & $122.50(3)$ & & \\
\hline $\mathrm{O} 2-\mathrm{C} 1-\mathrm{C} 2-\mathrm{C} 3$ & $68.74(6)$ & $\mathrm{C} 8-\mathrm{N} 1-\mathrm{C} 9-\mathrm{C} 14$ & $-123.99(6)$ \\
\hline $\mathrm{O} 1-\mathrm{C} 1-\mathrm{C} 2-\mathrm{C} 3$ & $-109.81(7)$ & $\mathrm{C} 8-\mathrm{N} 1-\mathrm{C} 9-\mathrm{C} 10$ & $61.14(6)$ \\
\hline $\mathrm{C} 1-\mathrm{C} 2-\mathrm{C} 3-\mathrm{C} 4$ & $98.14(7)$ & $\mathrm{N} 1-\mathrm{C} 9-\mathrm{C} 10-\mathrm{C} 11$ & $178.67(6)$ \\
\hline $\mathrm{C} 1-\mathrm{C} 2-\mathrm{C} 3-\mathrm{C} 8$ & $-81.68(7)$ & $\mathrm{C} 14-\mathrm{C} 9-\mathrm{C} 10-\mathrm{C} 11$ & $3.64(7)$ \\
\hline $\mathrm{C} 8-\mathrm{C} 3-\mathrm{C} 4-\mathrm{C} 5$ & $-0.98(6)$ & $\mathrm{N} 1-\mathrm{C} 9-\mathrm{C} 10-\mathrm{Cl} 2$ & $1.28(5)$ \\
\hline $\mathrm{C} 2-\mathrm{C} 3-\mathrm{C} 4-\mathrm{C} 5$ & $179.20(6)$ & $\mathrm{C} 14-\mathrm{C} 9-\mathrm{C} 10-\mathrm{Cl} 2$ & $-173.85(4)$ \\
\hline $\mathrm{C} 3-\mathrm{C} 4-\mathrm{C} 5-\mathrm{C} 6$ & $0.07(6)$ & $\mathrm{C} 9-\mathrm{C} 10-\mathrm{C} 11-\mathrm{C} 12$ & $-1.98(6)$ \\
\hline $\mathrm{C} 4-\mathrm{C} 5-\mathrm{C} 6-\mathrm{C} 7$ & $0.35(6)$ & $\mathrm{Cl} 2-\mathrm{C} 10-\mathrm{C} 11-\mathrm{C} 12$ & $175.44(5)$ \\
\hline $\mathrm{C} 5-\mathrm{C} 6-\mathrm{C} 7-\mathrm{C} 8$ & $0.17(7)$ & $\mathrm{C} 10-\mathrm{C} 11-\mathrm{C} 12-\mathrm{C} 13$ & $-0.85(6)$ \\
\hline $\mathrm{C} 6-\mathrm{C} 7-\mathrm{C} 8-\mathrm{C} 3$ & $-1.09(6)$ & $\mathrm{C} 11-\mathrm{C} 12-\mathrm{C} 13-\mathrm{C} 14$ & $2.89(7)$ \\
\hline $\mathrm{C} 6-\mathrm{C} 7-\mathrm{C} 8-\mathrm{N} 1$ & $177.74(6)$ & $\mathrm{C} 12-\mathrm{C} 13-\mathrm{C} 14-\mathrm{C} 9$ & $-0.26(8)$ \\
\hline $\mathrm{C} 4-\mathrm{C} 3-\mathrm{C} 8-\mathrm{C} 7$ & $1.48(6)$ & $\mathrm{C} 12-\mathrm{C} 13-\mathrm{C} 14-\mathrm{Cl1}$ & $-179.84(5)$ \\
\hline $\mathrm{C} 2-\mathrm{C} 3-\mathrm{C} 8-\mathrm{C} 7$ & $-178.70(6)$ & $\mathrm{N} 1-\mathrm{C} 9-\mathrm{C} 14-\mathrm{C} 13$ & $-177.66(6)$ \\
\hline $\mathrm{C} 4-\mathrm{C} 3-\mathrm{C} 8-\mathrm{N} 1$ & $-177.40(6)$ & $\mathrm{C} 10-\mathrm{C} 9-\mathrm{C} 14-\mathrm{C} 13$ & $-2.47(6)$ \\
\hline $\mathrm{C} 2-\mathrm{C} 3-\mathrm{C} 8-\mathrm{N} 1$ & $2.42(6)$ & $\mathrm{N} 1-\mathrm{C} 9-\mathrm{C} 14-\mathrm{Cl1}$ & $2.02(5)$ \\
\hline $\mathrm{C} 9-\mathrm{N} 1-\mathrm{C} 8-\mathrm{C} 7$ & $15.85(6)$ & $\mathrm{C} 10-\mathrm{C} 9-\mathrm{C} 14-\mathrm{Cl}$ & $177.20(4)$ \\
\hline $\mathrm{C} 9-\mathrm{N} 1-\mathrm{C} 8-\mathrm{C} 3$ & $-165.32(6)$ & & \\
\hline
\end{tabular}

Table Sup 2: Experimental and theoretical topological properties of the electron density at the bond critical points of Diclofenac. 


\begin{tabular}{|c|c|c|c|c|c|}
\hline Bonds & $\begin{array}{l}\rho_{B C P} \\
\left(\mathbf{e} / \AA^{3}\right)\end{array}$ & $\begin{array}{r}\nabla^{2} \rho \\
\left(\mathrm{e} / \AA^{5}\right)\end{array}$ & $\varepsilon$ & $\begin{array}{l}d_{1} \\
(\AA)\end{array}$ & $\begin{array}{l}d_{2} \\
(\AA)\end{array}$ \\
\hline \multirow[t]{2}{*}{$\mathrm{C} 2-\mathrm{C} 3$} & $1.65(2)$ & $-9.4(8)$ & $0.00(2)$ & 0.728 & 0.785 \\
\hline & 1.66 & -13.4 & 0.04 & 0.758 & 0.755 \\
\hline \multirow[t]{2}{*}{$\mathrm{C} 3-\mathrm{C} 4$} & $2.18(2)$ & $-18.9(7)$ & $0.26(2)$ & 0.686 & 0.707 \\
\hline & 2.09 & -20.7 & 0.22 & 0.685 & 0.707 \\
\hline \multirow[t]{2}{*}{$\mathrm{C} 3-\mathrm{C} 8$} & 2.11(2) & $-17.7(7)$ & $0.29(2)$ & 0.693 & 0.714 \\
\hline & 2.06 & -20.2 & 0.24 & 0.717 & 0.69 \\
\hline \multirow[t]{2}{*}{$\mathrm{C} 4-\mathrm{C} 5$} & $2.17(2)$ & $-18.8(5)$ & $0.19(4)$ & 0.708 & 0.685 \\
\hline & 2.09 & -20.9 & 0.19 & 0.689 & 0.702 \\
\hline \multirow[t]{2}{*}{$\mathrm{C} 5-\mathrm{C} 6$} & $2.17(2)$ & $-19.3(7)$ & $0.17(2)$ & 0.685 & 0.360 \\
\hline & 2.11 & -21.2 & 0.19 & 0.697 & 0.691 \\
\hline \multirow[t]{2}{*}{$\mathrm{C} 6-\mathrm{C} 7$} & $1.81(2)$ & $-15.8(8)$ & $0.02(2)$ & 0.708 & 0.374 \\
\hline & 2.08 & -20.7 & 0.20 & 0.700 & 0.692 \\
\hline \multirow[t]{2}{*}{$\mathrm{C} 7-\mathrm{C} 8$} & $1.85(3)$ & $-17.6(9)$ & $0.05(2)$ & 0.718 & 0.365 \\
\hline & 2.08 & -20.6 & 0.22 & 0.673 & 0.724 \\
\hline \multirow[t]{2}{*}{ C9-C10 } & $2.10(1)$ & $-17.5(4)$ & $0.27(2)$ & 0.698 & 0.709 \\
\hline & 2.05 & -19.8 & 0.27 & 0.700 & 0.707 \\
\hline \multirow[t]{2}{*}{ C9-C14 } & $2.14(2)$ & $-17.9(5)$ & $0.27(3)$ & 0.697 & 0.709 \\
\hline & 2.06 & -19.9 & 0.27 & 0.707 & 0.698 \\
\hline \multirow[t]{2}{*}{$\mathrm{C} 10-\mathrm{C} 11$} & $2.18(3)$ & $-19.7(8)$ & $0.23(2)$ & 0.709 & 0.681 \\
\hline & 2.09 & -20.8 & 0.23 & 0.663 & 0.727 \\
\hline \multirow[t]{2}{*}{$\mathrm{C} 11-\mathrm{C} 12$} & $2.16(2)$ & $-19.397)$ & $0.21(1)$ & 0.680 & 0.710 \\
\hline & 2.10 & -21.1 & 0.19 & 0.688 & 0.700 \\
\hline \multirow[t]{2}{*}{$\mathrm{C} 12-\mathrm{C} 13$} & $2.15(2)$ & $-19.1(7)$ & $0.19(1)$ & 0.711 & 0.679 \\
\hline & 2.10 & -21.1 & 0.20 & 0.700 & 0.688 \\
\hline \multirow[t]{2}{*}{ C13-C14 } & $2.18(2)$ & $-19.4(7)$ & $0.23(2)$ & 0.674 & 0.716 \\
\hline & 2.10 & -20.8 & 0.23 & 0.663 & 0.728 \\
\hline \multirow[t]{2}{*}{ C14-Cl1 } & $1.29(1)$ & $-1.8(4)$ & $0.11(5)$ & 0.960 & 0.777 \\
\hline & 1.35 & -7.2 & 0.07 & 0.995 & 0.743 \\
\hline \multirow[t]{2}{*}{$\mathrm{C} 10-\mathrm{Cl} 2$} & $1.31(2)$ & $-2.2(5)$ & $0.02(5)$ & 0.956 & 0.769 \\
\hline & 1.38 & -7.6 & 0.07 & 0.737 & 0.989 \\
\hline \multirow[t]{2}{*}{$\mathrm{C} 1-\mathrm{O} 1$} & $2.33(4)$ & $-27.7(2)$ & $0.09(3)$ & 0.813 & 0.495 \\
\hline & 2.17 & -7.6 & 0.04 & 0.444 & 0.867 \\
\hline \multirow[t]{2}{*}{$\mathrm{C} 1-\mathrm{O} 2$} & $2.83(8)$ & $-22.2(7)$ & $0.18(4)$ & 0.814 & 0.417 \\
\hline & 2.70 & -9.0 & 0.08 & 0.807 & 0.423 \\
\hline \multirow[t]{2}{*}{ C8-N1 } & $2.00(2)$ & $-16.6(1)$ & $0.12(2)$ & 0.822 & 0.593 \\
\hline & 1.92 & -19.3 & 0.08 & 0.551 & 0.865 \\
\hline \multirow[t]{2}{*}{ C9-N1 } & 2.13(3) & $-15.7(1)$ & $0.14(4)$ & 0.780 & 0.614 \\
\hline & 2.02 & -21.1 & 0.11 & 0.548 & 0.848 \\
\hline
\end{tabular}




\begin{tabular}{|l|l|l|l|l|l|} 
C4-H4 & $1.85(3)$ & $-18.1(7)$ & $0.05(1)$ & 0.723 & 0.360 \\
C5-H5 & 2.63 & -42.6 & 0.001 & 0.545 & 0.367 \\
& $1.81(2)$ & $-15.8(7)$ & $0.02(1)$ & 0.708 & 0.374 \\
C6-H6 & 2.63 & -42.5 & 0.004 & 0.546 & 0.367 \\
& $1.85(2)$ & $-17.6(8)$ & $0.05(2)$ & 0.718 & 0.365 \\
C7-H7 & 2.64 & -42.9 & 0.003 & 0.366 & 0.547 \\
& $1.78(2)$ & $-16.5(7)$ & $0.04(2)$ & 0.740 & 0.343 \\
C11-H11 & 2.63 & -42.7 & 0.008 & 0.364 & 0.549 \\
& $1.82(1)$ & $-16.1(6)$ & $0.03(2)$ & 0.727 & 0.356 \\
C13-H13 & 2.64 & -43.2 & 0.008 & 0.552 & 0.36 \\
& $1.81(2)$ & $-16.1(6)$ & $0.01(1)$ & 0.729 & 0.354 \\
C12-H12 & 2.64 & -43.2 & 0.008 & 0.359 & 0.553 \\
& $1.83(2)$ & $-17.7(7)$ & $0.06(2)$ & 0.719 & 0.364 \\
C2-H2A & 2.63 & -42.8 & 0.003 & 0.363 & 0.549 \\
& $1.72(2)$ & $-13.7(5)$ & $0.01(1)$ & 0.716 & 0.376 \\
C2-H2B & 2.42 & -36.4 & 0.01 & 0.358 & 0.596 \\
& $1.76(3)$ & $-14.1(6)$ & $0.01(1)$ & 0.716 & 0.375 \\
& 2.42 & -36.5 & 0.012 & 0.591 & 0.363 \\
\hline O1-H1B & $2.10(4)$ & $-23.7(3)$ & $0.003(4)$ & 0.754 & 0.226 \\
& 2.68 & -70.7 & 0.02 & 0.151 & 0.755 \\
\hline N1-H1A & $2.03(4)$ & $-21.2(1)$ & $0.05(2)$ & 0.756 & 0.259 \\
& 3.95 & -114.2 & 0.04 & 0.148 & 0.626 \\
\hline
\end{tabular}


The first line indicates the experimental values; the second line indicates the values obtained from the gas phase theoretical calculation. $\rho_{\mathrm{BCP}}(\mathbf{r}), \nabla^{2} \rho(\mathbf{r})$, electron density and the Laplacian of electron density at the BCPs; $\varepsilon$, bond ellipticity; $d_{1}, d_{2}$, the distance between BCP and each bonded atom.

Figure Sup1.Normal probability plot of $\left(F^{2}{ }_{\mathrm{o}}-F^{2}\right.$ ) using program DRKplot (Zhurov, Zhurova\& Pinkerton, J. Appl. Cryst. (2008) 41, 340-349). Weighting scheme used: $W=1 /\left[\sigma\left(F^{2}\right)\right]^{2}$. 
$\sin \theta_{\max } / \lambda$ is $1.04 A^{-1}$

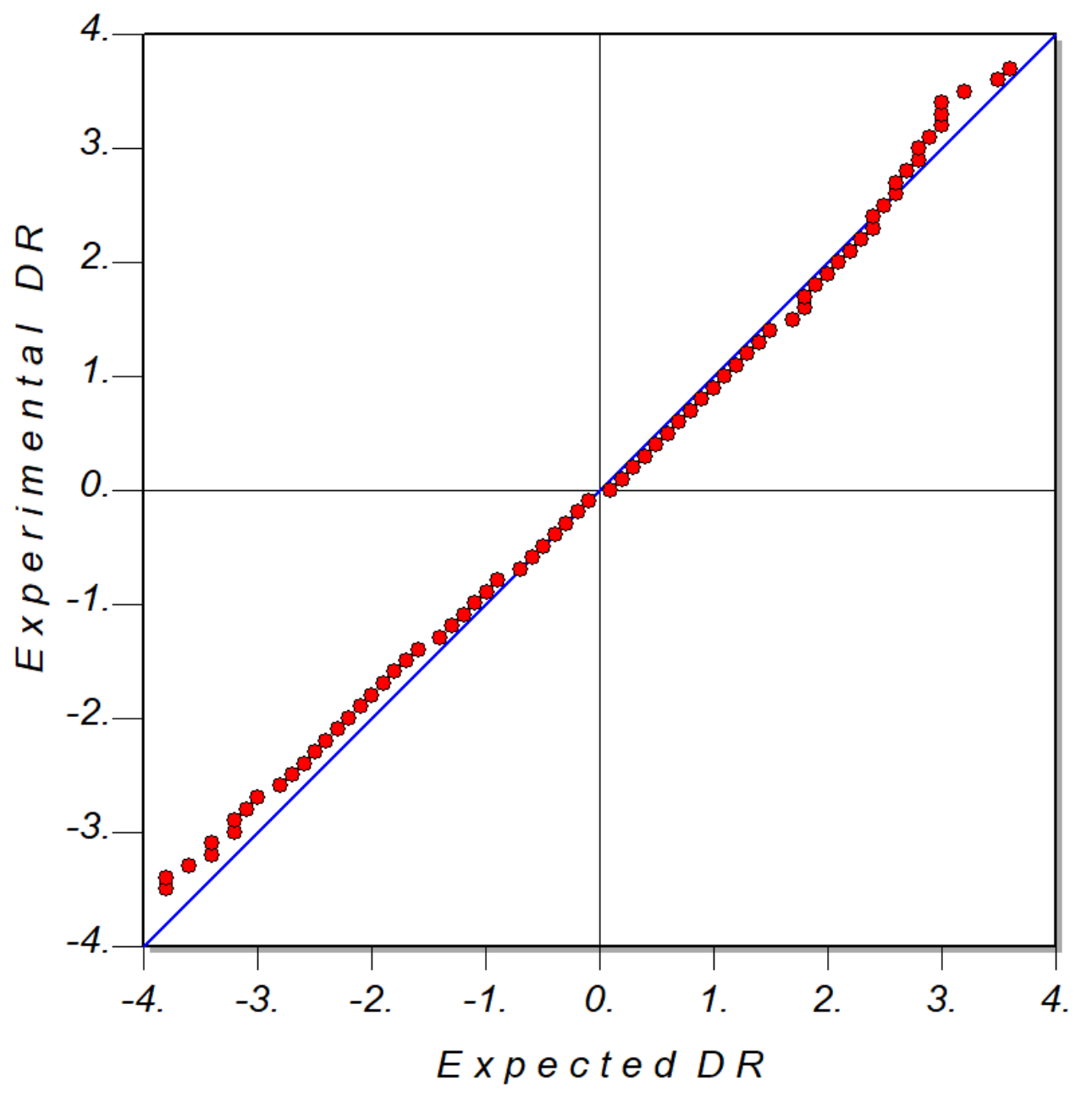


Figure Sup2. Variation of scale factor, $\Sigma\left(F \mathrm{o}^{2}\right) / \Sigma\left(F \mathrm{c}^{2}\right)$ with respect to resolution, obtained using program DRKplot (Zhurov, Zhurova\& Pinkerton, J. Appl. Cryst. (2008) 41, 340-349).

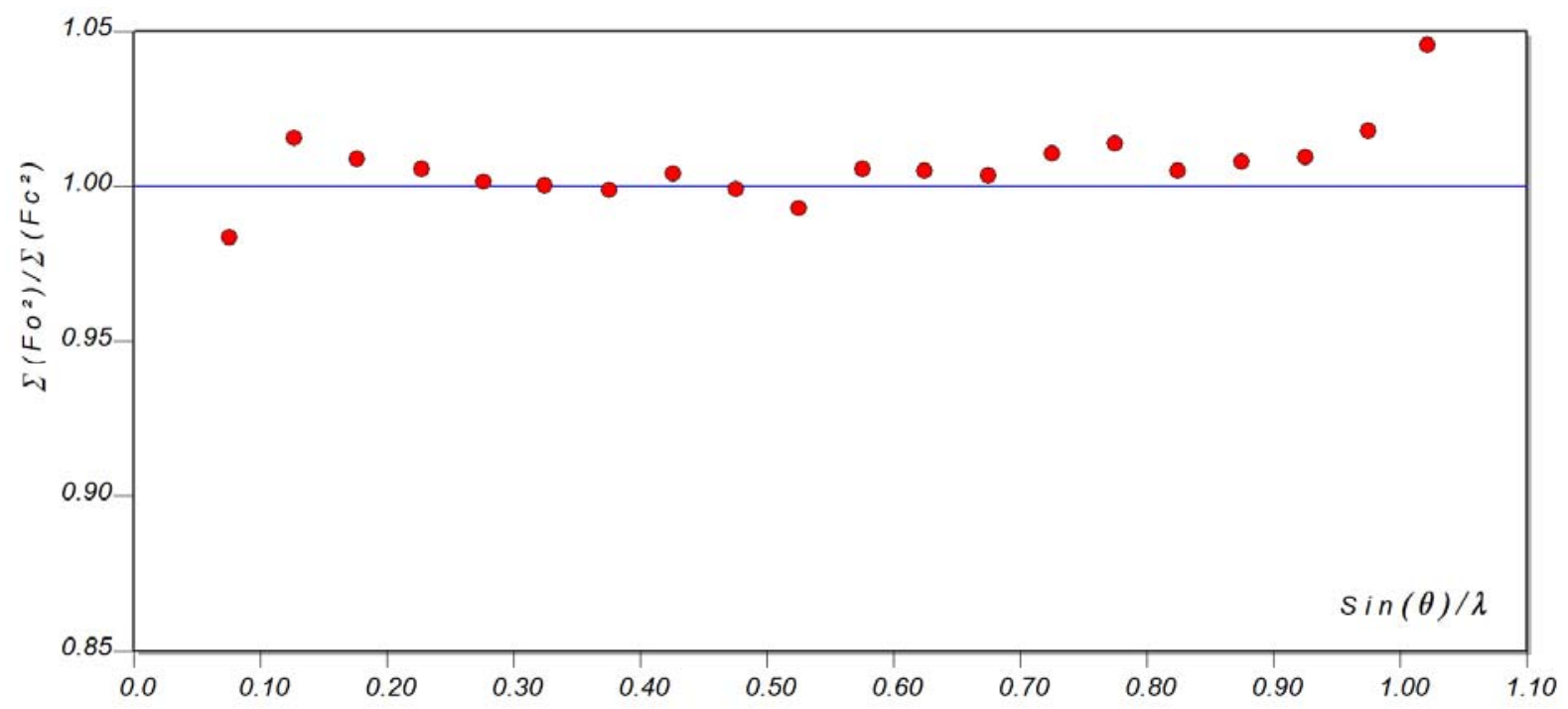


Figure Sup3. Fractal dimension $\left(d^{\mathfrak{f}}\right) v$. residual electron density $\rho\left(F_{\mathbf{O}}-F_{\mathbf{c}}\right)$ using all reflections.

(Meindl, K \& Henn, J., Acta Cryst. (2008). A64, 404-418). $\sin \boldsymbol{\theta}_{\max } / \boldsymbol{\lambda}$ is $1.04 A^{-1}$.

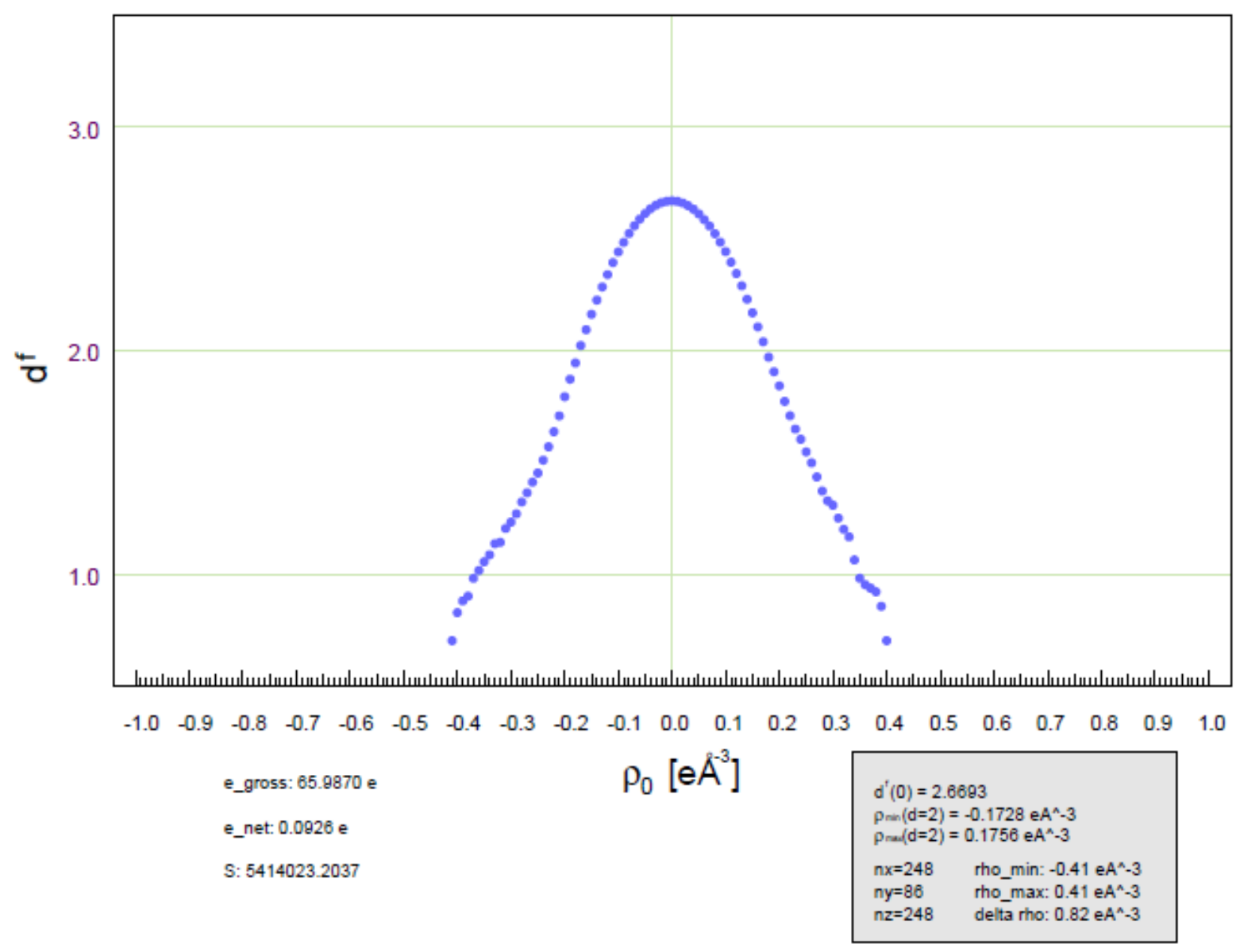

